\title{
Nitric Oxide-Dependent Pathways as Critical Factors in the Consequences and Recovery after Brain Ischemic Hypoxia
}

\author{
Joanna M Wierońska ${ }^{1}$, Paulina Cieślik ${ }^{1}$ (D) and Leszek Kalinowski ${ }^{2,3,4, *}$ \\ 1 Maj Institute of Pharmacology, Polish Academy of Sciences, Smętna Street 12, 31-343 Kraków, Poland; \\ wierons@if-pan.krakow.pl (J.M.W.); cieslik@if-pan.krakow.pl (P.C.) \\ 2 Department of Medical Laboratory Diagnostics-Biobank Fahrenheit BBMRI.pl, \\ Medical University of Gdansk, Debinki Street 7, 80-211 Gdansk, Poland \\ 3 Biobanking and Biomolecular Resources Research Infrastructure Poland (BBMRI.PL), Debinki Street 7 , \\ 80-211 Gdansk, Poland \\ 4 BioTechMed Center/Department of Mechanics of Materials and Structures, Gdansk University of Technology, \\ Narutowicza 11/12, 80-223 Gdansk, Poland \\ * Correspondence: leszek.kalinowski@gumed.edu.pl; Tel.: +48-58-349-1182
}

Citation: Wierońska, J.M.; Cieślik, P.; Kalinowski, L. Nitric Oxide-

Dependent Pathways as Critical Factors in the Consequences and Recovery after Brain Ischemic Hypoxia. Biomolecules 2021, 11, 1097. https://doi.org/10.3390/biom11081097

Academic Editor: Jerzy Beltowski

Received: 31 May 2021

Accepted: 20 July 2021

Published: 26 July 2021

Publisher's Note: MDPI stays neutral with regard to jurisdictional claims in published maps and institutional affiliations.

Copyright: (c) 2021 by the authors. Licensee MDPI, Basel, Switzerland. This article is an open access article distributed under the terms and conditions of the Creative Commons Attribution (CC BY) license (https:// creativecommons.org/licenses/by/ $4.0 /)$.

\begin{abstract}
Brain ischemia is one of the leading causes of disability and mortality worldwide. Nitric oxide $\left(\mathrm{NO}^{\bullet}\right)$, a molecule that is involved in the regulation of proper blood flow, vasodilation, neuronal and glial activity constitutes the crucial factor that contributes to the development of pathological changes after stroke. One of the early consequences of a sudden interruption in the cerebral blood flow is the massive production of reactive oxygen and nitrogen species (ROS/RNS) in neurons due to $\mathrm{NO}^{\bullet}$ synthase uncoupling, which leads to neurotoxicity. Progression of apoptotic or necrotic neuronal damage activates reactive astrocytes and attracts microglia or lymphocytes to migrate to place of inflammation. Those inflammatory cells start to produce large amounts of inflammatory proteins, including pathological, inducible form of NOS (iNOS), which generates nitrosative stress that further contributes to brain tissue damage, forming vicious circle of detrimental processes in the late stage of ischemia. S-nitrosylation, hypoxia-inducible factor $1 \alpha(\mathrm{HIF}-1 \alpha)$ and HIF- $1 \alpha$-dependent genes activated in reactive astrocytes play essential roles in this process. The review summarizes the roles of $\mathrm{NO}^{\bullet}$-dependent pathways in the early and late aftermath of stroke and treatments based on the stimulation or inhibition of particular $\mathrm{NO}^{\bullet}$ synthases and the stabilization of HIF-1 $\alpha$ activity.
\end{abstract}

Keywords: nitric oxide; cerebral ischemia; excitotoxicity; eNOS; nNOS; iNOS; oxidative/nitrosative stress; HIF-1 $\alpha$

\section{Brain Ischemic Stroke and the Role of NO Its Pathology}

Insufficient blood flow to a tissue results in hypoxia (the lack of an adequate oxygen supply at the tissue level) or anoxia (the absence of oxygen). Acute arterial thrombus formation, chronic narrowing of a supply artery and arterial vasospasm are the most critical factors contributing to the local or generalized deprivation of oxygen, which results in ischemia. In the 50-year-old and older age group, brain stroke is the second leading cause of disability [1] and, after coronary artery disease, constitutes the second most common cause of death worldwide [2].

As shown in vivo in transient forebrain ischemia model in rats, the mechanisms of neuronal death following ischemia include both apoptosis, i.e., a form of programmed cell death, highly regulated and controlled process that involves events such as cell shrinkage, nuclear fragmentation, chromatin condensation, chromosomal DNA fragmentation [3] and necrosis, a form of traumatic cell death that results from the disruption of membrane integrity, which attracts leukocytes to accumulate around the necrotic cells and to release cytokines [3], inducing collateral damage thus enabling the healing of the tissue. 
Among the variety of factors that contribute to the cellular events leading to ischemic neuronal death, the fundamental factors are N-methyl-D-aspartate receptor (NMDA)induced excitotoxicity and $\mathrm{NO}^{\bullet}$-dependent pathways which are functionally linked [4-6].

$\mathrm{NO}$ is formed by the oxidation of nitrogen and is biosynthesized endogenously from L-arginine, which is converted first to N-hydroxyl-arginine, then to L-citrulline and finally to $\mathrm{NO}$ in the presence of NADPH and tetrahydrobiopterin $\left(\mathrm{BH}_{4}\right)$ as cofactors [7]. The main enzymatic target of $\mathrm{NO}^{\bullet}$ is activation of guanylyl cyclase (GC) [8,9], which leads to cGMP production and the subsequent activation of a variety of proteins essential for a number of critical processes in the brain [9] amplifying the excitatory cell responses modulated by NMDA-dependent signaling [10].

At least three NOS isoforms are responsible for $\mathrm{NO}^{\bullet}$ synthesis, including neuronal NO synthase (nNOS), which mediates the production of $\mathrm{NO}^{\bullet}$ in neurons; the endothelial (eNOS) isoform, which is found on the inner surface of blood vessels. The activity of eNOS and nNOS, which are called constitutive NOS isoforms (cNOS), is dependent on $\mathrm{Ca}^{2+}$ and calmodulin complex, and the production of $\mathrm{NO}^{\bullet}$ is initiated in response to elevations in intracellular $\mathrm{Ca}^{2+}$ levels triggered by both mechanical forces and substances circulating in the blood (e.g., glutamate, acetylcholine, ATP) [11,12].

In contrast to cNOS, the activity of inducible $\mathrm{NO}^{\bullet}$ synthase (iNOS) is $\mathrm{Ca}^{2+}$-independent $[12,13]$. The enzyme is activated mostly in glial cells or leukocytes by certain cytokines, such as interferon- $\gamma$, tumor necrosis factor- $\alpha$ or interleukin- $1 \beta$, in response to inflammation [12,13].

In the physiological state, glutamate activates the synaptic pool of NMDA receptors and is rapidly taken up from the synaptic space by presynaptic mechanisms and astrocytes. Opening of NMDA ion channels and subsequent $\mathrm{Ca}^{2+}$ influx into the neurons activates constitutive nitric oxide synthases (cNOS) to produce nitric oxide (NO) [4-6].

Under pathological conditions, due to the "uncoupling" of NOS activity from electron donation by NADPH and/or reduced availability of L-arginine or $\mathrm{BH}_{4}$, electrons are transferred from NADPH to flavins via the reductase domain, forming superoxide $\left(\mathrm{O}_{2}^{\bullet-}\right)$, and other reactive oxygen species (ROS) $[11,14]$. $\mathrm{NO}^{\bullet}$ reacts with $\mathrm{O}_{2}^{\bullet-}$ to form reactive nitrogen species (RNS) including the highly toxic peroxynitrite $\left(\mathrm{ONOO}^{-}\right)$, leading to the production of other secondary components of nitroxidative stress, such as $\mathrm{NO}^{2+}, \mathrm{NO}_{2}$ and $\mathrm{OH}^{\bullet}$, which initiate a cascade of redox reactions [11,14].

iNOS produces much greater amounts of $\mathrm{NO}^{\bullet}$ than both eNOS and nNOS combined. Therefore, iNOS is often referred to as the "pathological" form of NO" synthase, as it may promote the production of $\mathrm{ONOO}^{-}$and subsequently highly reactive hydroxyl radicals $[14,15]$.

The key role of $\mathrm{NO}^{\bullet}$ in the brain is its impact on the components of the neurovascular unit. Thus, the vasodilation or vasoconstriction of blood vessels, neuronal excitability and glial cell functioning are dependent on $\mathrm{NO}^{\bullet}$ signaling mediated by constitutive NOS isoforms (nNOS and eNOS) (Figure 1) [11,16].

The distribution and concentration of $\mathrm{NO}^{\bullet}$ in brain tissue change after ischemic episode and differs both temporally and spatially postinjury. Time-dependent changes induced by ischemia are related in particular to the activity of individual NOS isoforms, and in general, $\mathrm{NO}^{\bullet}$ produced by nNOS or iNOS plays detrimental role [14]; while eNOS is neuroprotective [17]. The expression of nNOS increases rapidly, in parallel with membrane depolarization and $\mathrm{Ca}^{2+}$ elevation in the cells, while massive production of iNOS is observed several hours after ischemic episode [14]. Such correlations were observed predominantly in the animal model of cerebral ischemia-reperfusion based on middle cerebral artery occlusion (MCAO), which is usually used and is believed to reproduce the pattern of ischemic brain damage observed in many humans ischemic stroke patients $[18,19]$.

Based on these pre-clinical observations the early and late stage of the ischemia, alternatively called early and late neuronal post-ischemic damage, has been described in several research papers [14,20-23], and in reviews [24]. Clinical studies concerning the progression of ischemia damage and the rsole of $\mathrm{NO}^{\bullet}$ can be found elsewhere [25-29]. 

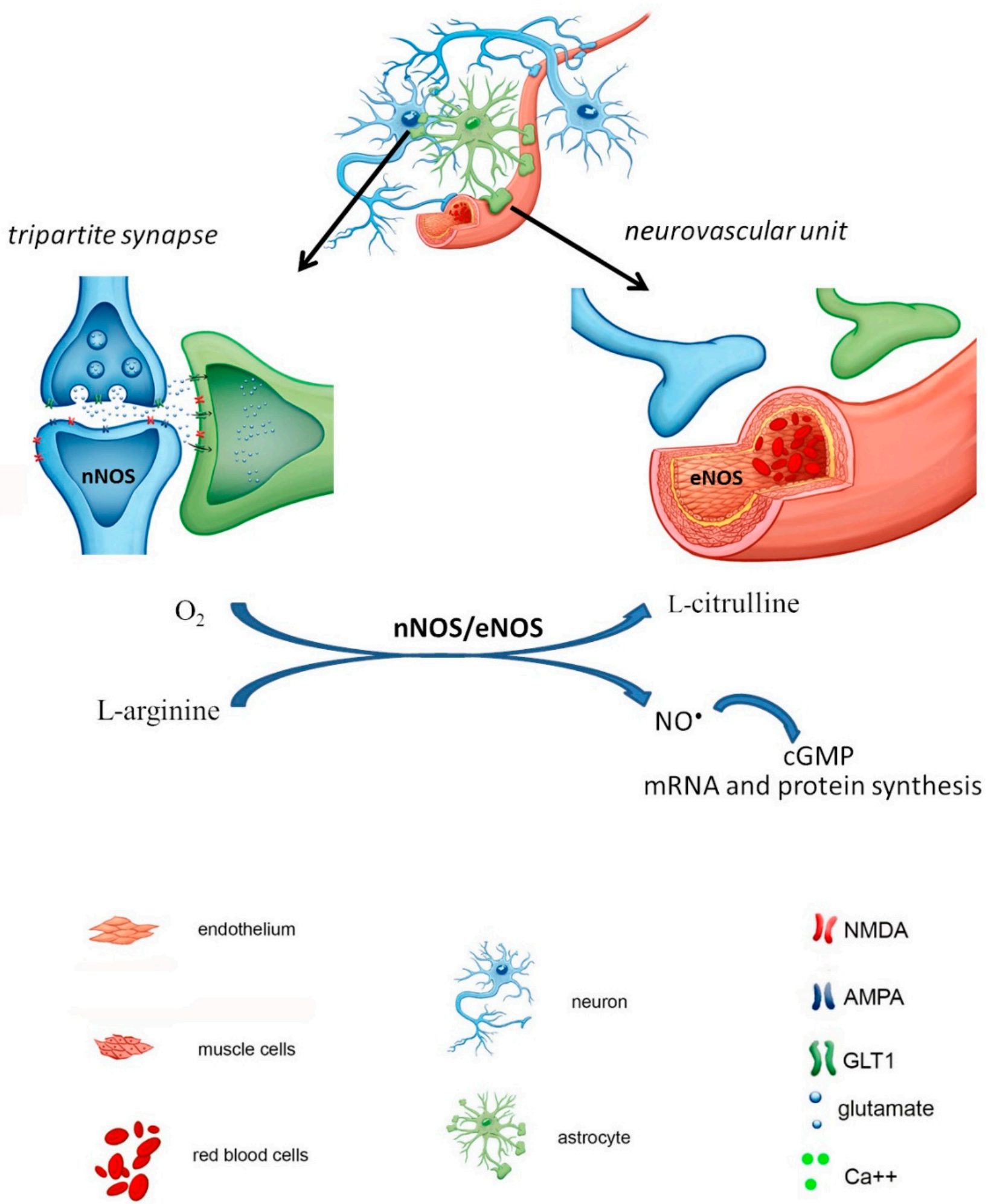

Figure 1. The activity of nNOS/eNOS dependent pathways in the brain under physiological conditions: glutamate released from the presynaptic neuron is rapidly uptaken by the astrocyte; nNOS and eNOS are kept at the normal level and both enzymes synthesize $\mathrm{NO}^{\bullet}$ which activates cGMP synthesis.

\subsection{Early Stage of the Ischemia (Early Neuronal Damage)}

The obstruction of blood flow by the clot dramatically reduces glucose and oxygen supply in ischemic brain region and triggers ischemic cascades, which include accumulation of lactate and malfunction of ion pumps $\left(\mathrm{Na}^{+} / \mathrm{K}^{+}\right.$-ATPase and $\left.\mathrm{Ca}^{2+} / \mathrm{H}-\mathrm{ATPase}\right)$, subse- 
quently inducing membrane depolarization and calcium ion $\left(\mathrm{Ca}^{2+}\right)$ overload. Membrane depolarization causes the release of excitotoxic amino acid glutamate and its translocation into the extracellular compartment. The reversal of the activity of glutamate transport proteins prevents glutamate reuptake which results in robust increase in glutamate level and activation of extrasynaptic NMDA receptors [4,16,30,31].

In vivo studies show, that in the MCAO model in rats, immediate early genes (c-fos, $\mathrm{c}$-jun) are activated by protein kinases and other second messengers shortly after the onset of ischemia.

The synthesis of $\mathrm{NO}^{\bullet}$ through nNOS is mainly related to calcium overload induced by glutamate in ischemic neurons [32]. The exacerbated activation of nNOS and the excess $\mathrm{NO}{ }^{\bullet}$ production due to uncoupled state, contributes to neurotoxicity and neurodegeneration by free radical formation [33-35].

Neurons are particularly sensitive to stress caused by ROS/RNS overproduction because of the relatively low levels of antioxidants compared with other cells. Physiologically, basal ROS/RNS production in neurons is constitutively generated by mitochondrial metabolism, which is higher than that in other cells due to the necessity to maintain neuronal circuit activity and synaptic transmission. Excessive nNOS activation under hyperactivation of NMDA receptors results in massive and uncontrolled generation of NO followed by the downstream formation of ROS/RNS, resulting in neuroinflammation and nitro oxidative burst. The prolonged destabilization of nNOS contributes to neurotoxicity and the potentiation of ischemic damage (Figure 2) [36,37]. Genetically engineered mice that overexpress the free radical scavenger, superoxide dismutase, have less edema formation than wild-type littermates confirming the detrimental role of free radicals in ischemia pathology [38-40].

A second glutamate-independent rise in $\mathrm{Ca}^{2+}$ is observed $2-3 \mathrm{~h}$ after an ischemic episode, further contributing to the activation of $\mathrm{Ca}^{2+}$-dependent enzymes (except NOS also proteases, phospholipases, cyclooxygenases, endonucleases) and leading to irreversible changes that promote the apoptotic and necrotic death of neurons [41-45].

In animal studies with the use of $\mathrm{nNOS}^{-/-}$knockout $(\mathrm{KO})$ mice, in the model of cerebral ischemia-reperfusion, the smaller infarct size comparing to their wild-type littermates was observed. Relative cerebral blood flow after reperfusion was also higher and the levels of nitrates was significantly decreased in $\mathrm{nNOS}^{-/-}$mice [46,47]. No 3-nitrotyrosine immunoreactivity, a marker for $\mathrm{ONOO}^{-}$formation associated with cell death, was reported in mutant mice deficient in nNOS activity, which were subjected to reversible MCAO [16].

In contrast to $\mathrm{nNOS}, \mathrm{NO}^{\bullet}$ generated by eNOS expressed in the endothelial cells has been suggested to have beneficial effects [17]. Here, eNOS not only promotes vascular dilation but also increases vascular smooth muscle cell proliferation and migration, and thereby enhances arteriogenesis after stroke [48].

In this case, eNOS deficient mice suffered from more severe ischemia-reperfusion injury in MCAO model, significantly reduced cerebral blood flow which subsequently resulted in greater infarct size $[46,47,49]$.

The results of in vivo studies clearly suggest that the generation of $\mathrm{NO}^{\bullet}$ and its neurotoxicity after reperfusion is closely related with the activity of nNOS. Additionally, nNOS-derived $\mathrm{NO}^{\bullet}$ may play a major role in early blood-brain barrier BBB disruption following transient focal cerebral ischemia [50]. 

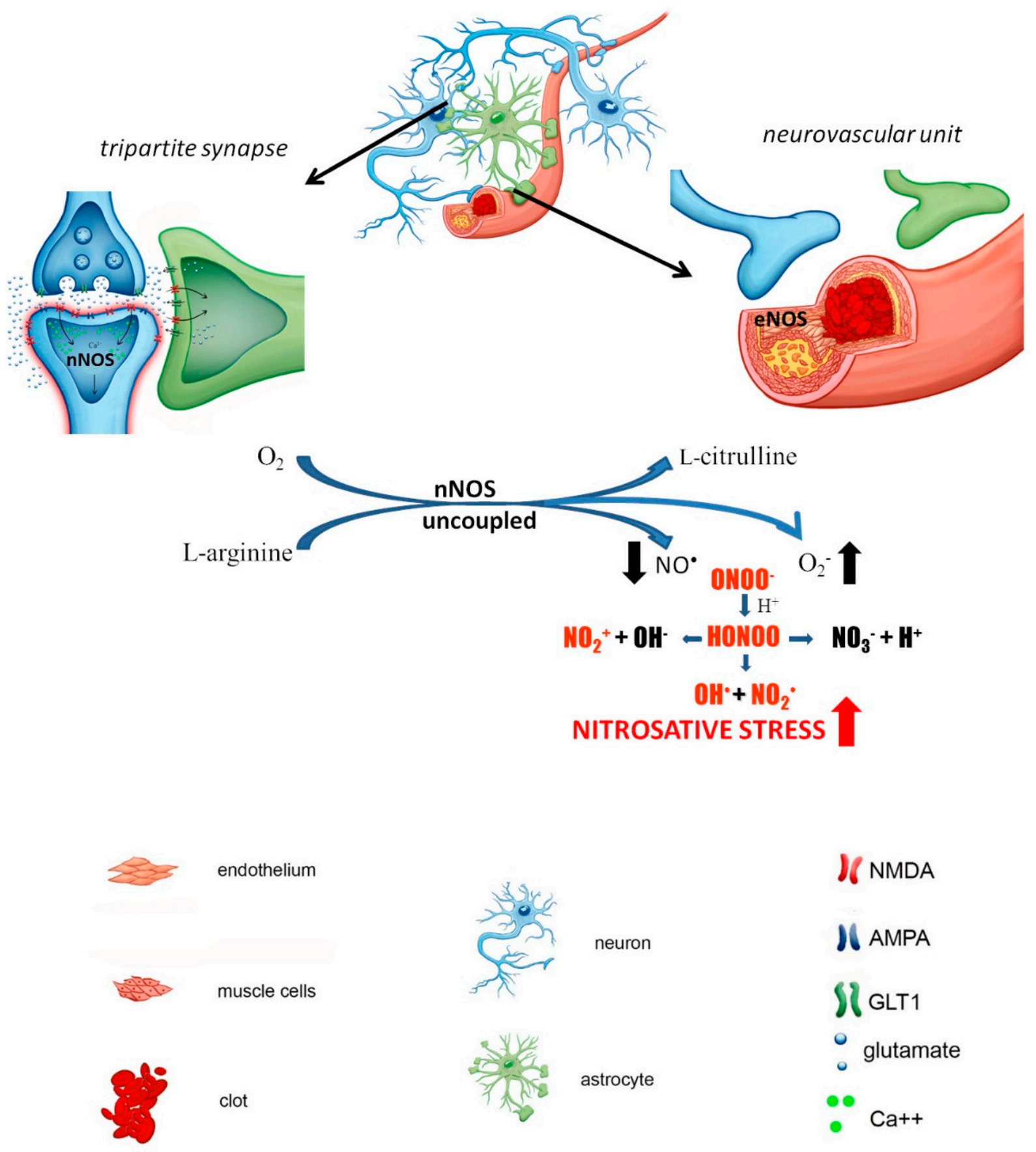

IS NMDA

U AMPA

\\{GLT1

glutamate

Ca++

Figure 2. Early stage of the ischemia (early neuronal damage (0-6 h after ischemic episode): when the clot is formed due to atherosclerotic plaque, under restriction of oxygen supply, the glutamate released by presynaptic neuron accumulates in the synaptic cleft due to reversed activity of GLT1 transporter in the astrocyte; this leads to overactivation of postsynaptic neuron, overactivation of voltage-dependent calcium channels and $\mathrm{Ca}^{2+}$ influx into postsynaptic neuron, that leads to overactivation of nNOS and its uncoupling, and accumulation of ROS/RNS, instead of cGMP.

\subsection{Late Stage of the Ischemia (Delayed Neuronal Damage)}

Immediate early gene products activate transcription sites on the cytokine genes such as tumor necrosis factor- $\alpha$ (TNF- $\alpha$ ) or interleukin-1 $\beta$ (IL-1 $\beta)$ that appear within hours after stroke. Appearance of cytokines attracts inflammatory cells such as neutrophils, that appear 4 to $6 \mathrm{~h}$ after a stroke [51,52]. P-selectin, E-selectin, vascular cell adhesion molecule (VCAM) and intercellular adhesion molecule (ICAM) appear on the vessels with different time courses, but the ultimate effect is that neutrophils rolling along the vessel attach and 
cross into the brain. At later times macrophages become the predominate cell type in the injured site [15,53].

The role of glia cells (astrocytes and microglia) is pivotal in progressing cerebral ischemia. Astrocytes play critical role BBB integrity and the maintenance of extracellular ion homeostasis by buffering excitatory transmitters released by neurons and producing trophic factors that support neuronal growth and survival. In response to pathological situations in surrounding tissue such as ischemic injury astrocytes undergo morphological, molecular and functional changes and become reactive astrocytes [54] The changes associated with the reactive state can directly impact synaptic transmission and neuronal circuit activity, thereby potentially contributing to the pathological changes observed after ischemia [55].

On the other hand, resting microglia in the mature brain is a powerful weapon under pathological activation. Following ischemia, as a result of rapid neuronal death, microglia migrates to damaged tissue to exert a neuroprotective effect by clearing dead tissue, inhibiting cytotoxic neuronal damage and releasing neuroprotective growth factors. However, microglial activation triggers iNOS production, which, together with the parallel appearance of reactive astrocytes, results in massive iNOS expression observed relatively late after an ischemic episode (after approximately $24 \mathrm{~h}$ ) and generation of ROS/RNS [51,55-58]. In some brain areas, astrocytes also express nNOS, which may be tonically active after chain reactions initiated by ischemia. However, some contrary reports indicate the minor role of microglial iNOS in mediating brain injury after stroke [59].

In contrast to nNOS, the induction of iNOS expression begins $12 \mathrm{~h}$ after induction of ischemia, increases progressively over time and reaches maximal levels after approximately 24-48 $\mathrm{h}$ as shown in transient MCAO model in animals [60]. The other in vivo studies confirm that NO derived from iNOS appears to contribute to neurotoxicity after ischemic stroke. The infarct and the motor deficits produced by MCAO were smaller in iNOS knockouts than in wild-type mice confirming that iNOS-derived NO $\mathrm{NO}^{\bullet}$ is one of the factors contributing to the expansion of the brain damage that occurs in the late stage of postischemic period [61]. Furthermore, the reduction of infarct size and improvement of neurological deficits was not observed up to $24 \mathrm{~h}$ after MCAO, indicating that iNOS does not participate in the initiation of ischemic brain damage [61].

Pathological glial activation escapes endogenous control and turns into an autoaggressive pathomechanism that contributes to secondary neuronal damage occurring after brain ischemia [58]. Leukocytes accumulating at the site of neuronal necrosis act as an additional barrier to this cascade of destructive events by secreting cytokines, including interferon- $\gamma$ and interleukins (Figure 3).

Overall increased activity of nNOS/iNOS isoforms results in the subsequent production of $\mathrm{NO}^{\bullet}$ in neurons, glia, neutrophils and the rest inflammatory cells inducing the release of inflammatory factors that promote cytotoxicity, including the increased activation of cell adhesion molecules, cytokines, TNF $\alpha$ and matrix metalloproteinases (MMPs) [62]. $\mathrm{TNF} \alpha$, caspases and MMPs are particularly important in triggering apoptotic signals in cells and contribute to BBB damage, neurotoxic substance release, free radical generation, oxidative stress and brain edema [63,64]. As a result, after hours and days the infarct size expands due to excitatory amino acid release, loss of ion homeostasis, decreased $\mathrm{pH}$, inflammation and edema, causing additional damage and apoptosis in the surrounding areas [65]. The strategy for post-ischemic neuroprotective therapies is to target the peri-infarct or penumbra region to prevent or rescue the spreading damage of the initial infarct. 

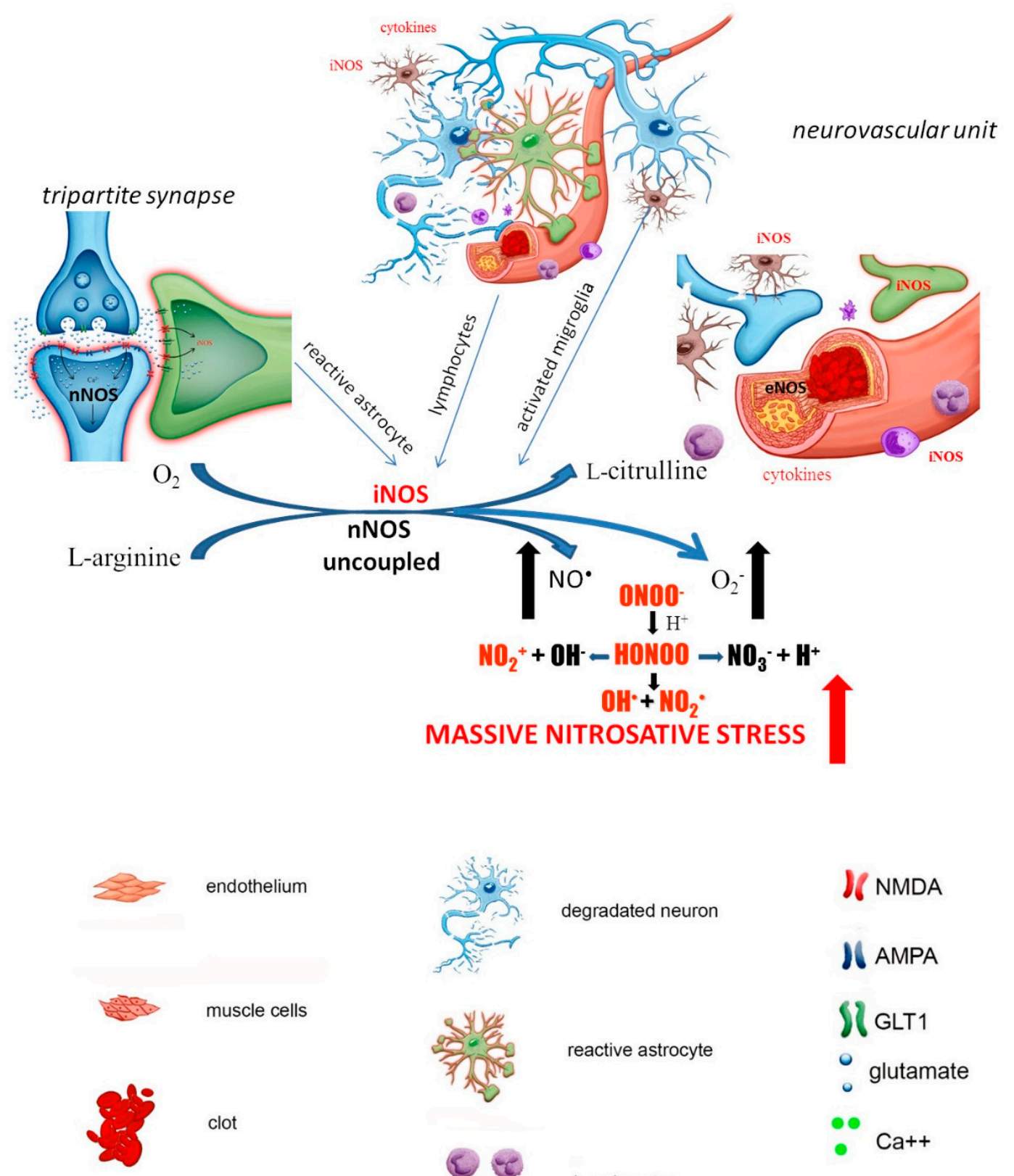

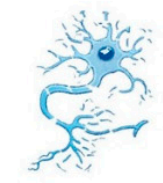

degradated neuron
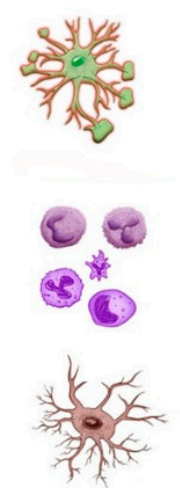

lymphocytes

microglia
I/ NMDA

IN AMPA

S? GLT1

reactive astrocyte

- glutamate

- $\mathrm{Ca}++$

Figure 3. Late stage of the ischemia (delayed neuronal damage (begins several hours after episode and reaches maximal level after 24-48 h): parts of dead neurons attract leucocytes and microglia, which accumulate in the place of the stroke releasing cytokines that start to induce the production of iNOS in these cells. Additionally, astrocytes undergo morphological, molecular and functional remodeling in response to injury and also becoming a source of proinflammatory cytokines and iNOS. Thus, the cascade of events triggered by ischemia leads to massive production of cytokines and accumulation of proinflammatory cells with high activity of iNOS. Under these circumstances, in the strong deprivation of tetrahydrobiopterin $\left(\mathrm{BH}_{4}\right)$ and/or substrate L-arginine, all uncoupled NOS isoforms generate simultaneously high amounts of both $\mathrm{NO}^{\bullet}$ and $\mathrm{O}_{2}{ }^{\bullet-}$ favoring production of $\mathrm{ONOO}^{-}$. The uncoupling of NOS isoforms can be additionally potentiated by $\mathrm{O}_{2}{ }^{\bullet-}$ overproduction from other enzymatic sources in the cells accumulated in ischemic lesion, such as upregulated $\mathrm{NAD}(\mathrm{P}) \mathrm{H}$-oxidase. It finally results in the generation of massive ROS/RNS and a vicious molecular circle is formed which aggravates the neurodegeneration process. 
Reassuming, ischemic brain injury involves a complex interaction between leukocytes, glia, neurons and the endothelium, which form a vicious chain of events that results in massive and continuous production of iNOS resulting is subsequent generation of ROS/RNS $[59,60]$. The pathological events associated with ischemic brain injury involve energy failure, oxidative stress, acidosis, disruption of ion homeostasis, neuronal cell excitotoxicity or inflammation and evolve progressively over time. The early and late stages of ischemia described above concern not only sequential $\mathrm{NO}^{\bullet}$ production but also immunological responses (which are in part related to $\mathrm{NO}^{\bullet}$ generation) described elsewhere in more details (for review see: $[66,67]$ ).

\section{NO-Dependent Factors Aggravating Ischemic Cascade}

In addition to guanylyl cyclase activation and subsequent initialization of cGMP production (or pathological generation of ROS/RNS), $\mathrm{NO}^{\bullet}$-mediated processes control the functioning of many proteins and genes expression. Among them, s-nitrosylation and HIF- $1 \alpha$ stabilization seem to be of importance in pathophysiology of brain ischemia.

\subsection{S-Nitrosylation}

The $\mathrm{NO}^{\bullet}$-mediated S-nitrosylation process is a redox-based posttranslational modification that modulates protein function and activity. S-nitrosylation is the chemical reaction of an $\mathrm{NO}^{\bullet}$ moiety with the sulfhydryl groups of target proteins, which leads to the formation of S-nitrosothiols (R-SNO), producing S-nitrosylated proteins (SNO-proteins) [68].

S-nitrosylation can occur both extracellularly and intracellularly [69]. The S-nitrosylation of the regulatory binding partners of transcription factors (TFs) (for example, HIF-1 $\alpha$ ) may impose an extranuclear influence on their activation, stability and nuclear targeting $[69,70]$. On the other hand, the S-nitrosylation of critical redox-sensitive Cys residues in the DNAbinding or allosteric sites of TFs invokes alterations in gene expression [71,72]. Finally, S-nitrosylation may regulate protein function by the covalent addition of an NO group to a cysteine thiol/sulfhydryl group ( $\mathrm{RSH}$ or, more properly, thiolate anion, $\mathrm{RS}^{-}$) to form S-nitrosothiol derivatives (RS-NO), which is the most important aspect of the Snitrosylation process [70]. The reaction is mediated by $\mathrm{NO}^{\bullet}$-related species including $\mathrm{NO}^{\bullet}$, $\mathrm{NO}^{-}$(nitroxyl anion, which is $\mathrm{NO}^{\bullet}$ with one additional electron) and $\mathrm{NO}^{+}$(nitrosonium ion, which has one fewer electron than $\mathrm{NO}^{\bullet}$ ) [70].

In addition to the process of S-nitrosylation, functional equivalents of $\mathrm{NO}^{+}$can be transferred from one nitrosothiol to another in a process called transnitrosylation, whereby an $\mathrm{NO}^{\bullet}$ moiety is transferred from a SNO-protein to a free thiol on another protein, which occurs when two proteins interact directly and possess appropriate redox potentials to allow electron transfer [73].

Aberrant S-nitrosylation occurs as a consequence of exacerbated nitrosative stress via the excessive production of $\mathrm{NO}^{\bullet}$, which nitrosylates cysteine thiols with only partial SNO motifs or located more distant from the $\mathrm{NO}^{\bullet}$ source [74]. These aberrantly S-nitrosylated proteins may contribute to pathological changes by triggering protein misfolding, mitochondrial dysfunction, transcriptional dysregulation, synaptic damage and neuronal injury [68]. In contrast, some SNO-proteins lose $\mathrm{NO}^{\bullet}$ groups from their Cys thiols and undergo denitrosylation, which contributes to the regulation of the SNO signaling cascade [73]. Therefore, both S-nitrosylation and denitrosylation regulate protein activity and may be involved in pathological processes.

Under physiological conditions, nNOS is S-nitrosylated by $\mathrm{NO}^{\bullet}$. The studies were performed both in vitro in HEK223 cell lines, cultured primary cortical neurons treated with OGD/reoxygenation and in vivo in rat hippocampus during cerebral ischemia-reperfusion. In all experimental schedules the enzyme is S-nitrosylated in resting or physiological state and undergoes significant denitrosylation under oxygen deprivation, which is coupled with its increased activity [75]. The subsequent increase in $\mathrm{NO}^{\bullet}$ production mediates the S-nitrosylation of proteins that initiate apoptotic signals in neurons, such as GluR6, c-Jun N-terminal kinase 3, phosphatases or tensin homolog [76]. 
In contrast to nNOS, the process of S-nitrosylation inhibits the activity of eNOS by inducing dimer disruption, dephosphorylation and changes in the subcellular targeting status as shown in vitro $[77,78]$.

Two of the most important proteins that undergo aberrant S-nitrosylation in response to ischemic injury are GAPDH $[79,80]$ and matrix metalloproteinase 9 (MMP9) [81]. GAPDH has been implicated in neurotoxicity and neurodegeneration and regulates transcriptional activation, apoptosis initiation, ER to Golgi vesicle shuttling and fast axonal or axoplasmic transport [82]. Following an ischemic episode, GAPDH accumulates rapidly both in the ischemic core and in penumbral apoptotic neurons as shown in vivo using MCAO model in rats [83]. Aberrant GAPDH s-nitrosylation, translation to nucleus, concomitant neuronal death occur during the early stages of reperfusion as shown, e.g., in the rat four-vessel occlusion ischemic model [80].

MMP9 belongs to the zinc metalloproteinase family, which is involved in the degradation of the extracellular matrix. The enzyme is acutely activated during ischemia and is selectively S-nitrosylated by $\mathrm{NO}{ }^{\bullet}$ during cerebral ischemia in vivo [81]. In in vitro studies s-nitrosylation of the cysteine switch at the active site of the enzyme together with ROSmediated oxidation of MMP9 to sulfinic or sulfonic acid derivatives triggered the apoptotic form of cell death [81], suggesting a potential extracellular proteolysis pathway to neuronal cell death in which s-nitrosylation activates MM9.

\subsection{Hypoxia-Inducible Factor $1 \alpha(H I F-1 \alpha)$}

HIF- $1 \alpha$ is the primary mammalian transcription factor specifically regulated by hypoxia and plays an essential role in cellular and systemic $\mathrm{O}_{2}$ homeostasis by regulating the expression of genes important in tissue survival, that regulate glycolysis, erythropoiesis, angiogenesis or catecholamine metabolism [84].

HIF is primarily regulated by changes in protein stability and transcriptional activity in oxygen-dependent manner. Under physiological conditions HIF- $1 \alpha$ is rapidly degraded and $\alpha$ subunit is hydroxylated by asparagine and proline residues by the family of prolyl4-hydroxylase domain (PHD) proteins and factor inhibiting HIF (FIH), whose activity is dependent on molecular oxygen, ferrous iron, 2-oxoglutarate [85-87]. In response to low tissue oxygenation during ischemic stroke, the activity of PHD and FIH declines resulting in stabilization of HIF- $1 \alpha$, its accumulation within the cell and translocation into the nucleus. It results in the transcriptional activation of several dozen hypoxiaresponsive genes through binding the hypoxia-responsive element (HRE) in their promoter region [88-91].

The activity of HIF- $1 \alpha$ is regulated by NO via the mechanism of S-nitrosylation. NO metabolites such as S-nitrosoglutathione (GSNO) and peroxynitrite stabilizes or destabilizes HIF- $1 \alpha$, respectively [92-94].

The impact of HIF- $1 \alpha$ on neuronal survival upon stroke is controversial, as it mediates both anti- and pro-survival genes [85]. Up regulation of vascular endothelial growth factor (VEGF) or erythropoietin (EPO) promotes adaptation to hypoxic/ischemic stress [95] and results in reduced infarct size after cerebral ischemia in MCAO model in rodents [58,85]. The HIF- $1 \alpha$ dependent activation of eNOS transcription and subsequent NO release in the endothelium also contribute to reduction of ischemia infarct volume also shown in MCAO model [96]. Exogenously administered NO metabolite S-nitrosoglutathione (GSNO) was found not only to stabilize HIF- $1 \alpha$ and to induce HIF- $1 \alpha$-dependent genes but also to stimulate the regeneration process and to aid in functional recovery in traumatic brain injury animal model [93].

On the other hand HIF- $1 \alpha$ regulates iNOS transcription preserving iNOS translation during ischemia, thus contributing to progressive ischemia-induced inflammation [97,98].

Tissue-specific knockouts have also given conflicting results on the role of HIF- $1 \alpha$ during ischemia. The studies of Helton et al. showed that the brains from neuron-specific HIF- $1 \alpha$ deficient mice were protected from hypoxia-induced cell death, when subjected to normobaric chamber or bilateral carotid artery occlusion (BCAO) model, suggesting 
that decreasing HIF- $1 \alpha$ level can be neuroprotective [84]. Additionally, in HIF- $1 \alpha \mathrm{KO}$ mice genes involved in apoptotic pathway were uniquely downregulated when compared with WT animals. Endothelial-specific HIF- $1 \alpha$ knock-out reduced BBB permeability and brain infarction in diabetic mice subjected to MCAO procedure [99]. In in vitro studies, in primary cortical neuron cultures, silencing HIF- $1 \alpha$ attenuated the accumulation of iNOS [100].

On the other hand in the studies of Baranova et al. neuron-specific inactivation of HIF- $1 \alpha$ increased brain injury in mice MCAO model [101]. Additionally, neuron-specific PHD inactivation which resulted in up-regulation of HIF-1 $\alpha$ lead to smaller infarct size and reduced edema formation in transient MCAO model in mice [102].

In the models of permanent MCAO or acute phase of ischemic stroke in mice the expression of HIF- $1 \alpha$ was enhanced in the place of injury, causing the massive production of iNOS [103], indicating that activation of HIF- $1 \alpha$ might be involved in the mechanisms through which iNOS promotes cell death or survival constituting a critical factor in widespread inflammation and subsequent pathological events. Another studies showed that intermittent hypoxic conditions after brain ischemia displayed a neuroprotective effect, and despite relatively high expression of HIF- $1 \alpha$, lower expression of iNOS in the border between infarcts and normal tissue was observed, suggesting that overactivation of HIF- $1 \alpha$ may suppress the activation of microglia in ischemic mice [104]. Enhanced HIF- $1 \alpha$ activation was responsible for triggering the transcription of HIF-regulated genes (VEGF, erythropoietin, eNOS), reduced infarct size and caspase- 3 activation in MCAO or common carotid arteries occlusion models in mice [96]. Increase HIF- $1 \alpha$ was accompanied by increased iNOS expression as shown in MCAO-reperfusion injury model in rats [105].

In in vitro studies the upregulation of HIF- $1 \alpha$ signaling was shown to improve cGMP production following ischemia through the maintenance of cGMP protein kinase activity [106], thus preventing the NO-mediated production of ROS/RNS instead of cGMP.

Overall, the role of HIF- $1 \alpha$ in ischemia remains inconclusive, but despite controversial results the role of HIF- $1 \alpha$ was shown to be of special importance in ischemia preconditioning and may either promote or prevent neuronal survival [107]. Partially the pro-survival and pro-inflammatory roles in the ischemic brain might depend on the injury model, time point or cell type assessed [101,108].

The contradictory results indicate that phenotype and transcriptional response to hypoxia in vivo is much more complex that would have been supposed. The brain has multiple ways of inducing HIF- $1 \alpha$-dependent genes involved in the response to hypoxia (that promote erythropoiesis, angiogenesis or vasodilation), and one of the alternatives is HIF- $2 \alpha$ [109-112]. HIF- $1 \alpha$ and HIF- $2 \alpha$ combined KO mice exhibited reduced expression of the anti-survival genes in MCAO model in mice [85]. Even though the mice initially performed better, became more impaired $72 \mathrm{~h}$ after reperfusion, accompanied by increased apoptosis and reduced angiogenesis. HIF- $1 \alpha$ and HIF- $2 \alpha$ can partially compensate for each other, although specific target genes are differentially regulated after ischemia. Combined loss of neuronal HIF- $1 \alpha$ and HIF- $2 \alpha$ impairs functional recovery after cerebral ischemia, which may be beneficial predominantly in the early phase after stroke, indicating a timely regulated activation-inhibition of hypoxia-regulated cytoprotective and damaging factors which may be important for the functional outcome after stroke [85].

Another example of mutuality that may promote proapoptotic genes in response to hypoxia is p53/HIF-1 $\alpha$ interaction [113-115]. Specific disruption of this interplay (attributable to the lack of HIF- $1 \alpha$ ) leads to downregulation and loss of expression of genes that promote cell death $[84,98]$.

\section{Treatment Strategies}

As discussed above, a variety of factors contribute to the severity of stroke and its long-term consequences. Treatment strategies based on $\mathrm{NO}^{\bullet}$ signaling may lower the risk of severe and irreversible complications after stroke, but they may also have detrimental effects and must therefore be provided with caution. 
The advantage of $\mathrm{NO}^{\bullet}$-based therapies is the possibility of modulating endogenous mechanisms activated after cerebral ischemia with exogenously applied compounds. The objective is to promote neuroprotective outcomes and integrate cellular signaling pathways at different stages of brain damage. The intervention time, pharmacokinetics, pharmacodynamics and activities of the compounds are critical to successfully counteract the consequences of stroke.

The present knowledge indicates that the therapeutic window to reduce the pathological consequences of stroke, essentially neuronal damage, is estimated as 0-6 h for primary interventions $[116,117]$ and may extend up to $24 \mathrm{~h}$ poststroke.

As discussed above, NO-mediated actions clearly indicate that the activation of eNOS contributes to proper vasodilation, exerts antioxidant, anti-inflammatory and antiatherogenic effects, and regulates glucose uptake and insulin sensitivity [118,119], thus exerting protective effects in stroke. In contrast, the inhibition of nNOS and iNOS, the main generators of free radicals, alternatively elimination of free radicals, may counteract neurodegeneration.

\subsection{Free Radical Scavengers}

Reperfusion of ischemic areas can exacerbate ischemic brain damage through the generation of ROS/RNS (e.g., $\mathrm{O}_{2}{ }^{\bullet-}$, hydroxyl radicals and $\mathrm{ONOO}^{-}$) by excessive production of both $\mathrm{NO}^{\bullet}$ and $\mathrm{O}_{2}{ }^{--}$by nNOS and iNOS. It has been reported that excess of $\mathrm{NO}^{\bullet}$ immediately reacts with $\mathrm{O}_{2}{ }^{\bullet-}$ to form $\mathrm{ONOO}^{-}[120,121]$, which is responsible for the nitration of both free and protein bound tyrosine residues which are known to disrupt cell signaling cascades leading to tissue injury $[120,121]$. Therefore, enhanced degradation of ROS/RNS with pharmacological agents has been found to limit the extent of brain damage following stroke-induced excess of $\mathrm{NO}^{\bullet}$ generation. Elimination of free radicals attenuates cytokine formation that drives up regulation of inflammatory proteins including iNOS.

On the other hand ROS provides a redox signal for hypoxic HIF-1 $\alpha$ activation [122]. Assuming, that under specific pathological conditions, increased activity of HIF-1 $\alpha$ is responsible for ischemia-induced detrimental effects, application of anti-oxidants eliminates ROS and consequently reduces HIF-1 $\alpha$ levels by its destabilization and loss of transcriptional activity [123].

Under normal conditions, endogenous protective enzyme systems, such as superoxide dismutase (SOD) and reduced glutathione (GSH), limit the overproduction of free radicals. However, their capacities may be overwhelmed by pathological changes when free radical generation is uncontrolled. Removal of pathologically produced free radicals may be regarded as a viable approach to neuroprotection and may be achieved by scavenging or trapping free radicals. Among the compounds that possess free radical scavenging properties are nitrones, thiols, iron chelators, phenols and catechols. Tirilazad, ebselen and edaravone are examples of compounds with scavenging activity, and compounds with free radical trapping properties include NXY-059 and NSP-116.

Edaravone (Radicut) is a free radical scavenger marketed in Japan to treat acute ischemic stroke [124]. Edaravone scavenged $\bullet \mathrm{HO}, \mathrm{NO}^{\bullet}$ and $\mathrm{ONOO}^{-}$in a concentrationdependent manner [125-127]. The efficacy of the drug ranges from large clinical improvements to modest effects measured with standard stroke scales when administered up to $72 \mathrm{~h}$ following ischemic stroke $[128,129]$.

Tirilazad mesylate, a lazaroid, has been investigated as a neuroprotective agent in patients after acute ischemic stroke. The compound was ineffective in treating acute ischemic stroke [130,131]. Another seleno-organic compound, ebselen, was shown to reduce delayed ischemic neurological deficits after SAH [132] and to improve outcomes after stroke $[133,134]$.

\subsection{Enhancement of NO Production}

L-arginine, a substrate for $\mathrm{NO}^{\bullet}$ biosynthesis, is an obvious candidate of choice to improve NO bioavailability. The administration of L-arginine increased regional blood 
flow and prevented tissue damage in the rat MCAO model [135-137]. However, contradictory results with L-arginine administration were obtained that showed a beneficial effect [135-137], no effect [138] and the potentiation of pathological changes [139,140]. These effects may result from the fact that L-arginine enhances $\mathrm{NO}^{\bullet}$ synthesis via all three isoforms [141]; therefore, synthesis of potentially detrimental NO ${ }^{\bullet}$ from iNOS or nNOS may counteract the neuroprotective effects of eNOS activation. The ability of L-arginine to stimulate the release of hormones such as insulin [142], glucagon [143], growth hormone [144] or catecholamines [145] and its ability to transform into toxic byproducts such as polyamines or agmatine [146-149] are also limitations of its use.

$\mathrm{NO} \bullet$ donors, such as organic nitrates, sodium nitroprusside (SNP), sydnonimines, S-nitrosothiols, NONOates and hybrid donors potentiate $\mathrm{NO}^{\bullet}$ production and thus may potentially be regarded as treatment strategies.

Administration of DETA/NONOate [150], SNP [151,152], 3morpholinosydnonimine [153,154], ZJM-289 [155] or LA-419 [156,157] significantly increased cell proliferation and/or reversed ischemia-induced tissue damage in the selected structures of the rat brain. Stimulation of eNOS activity with concomitant suppression of nNOS and iNOS function was observed [155-157]. Beyond this point, neurovascular toxicity instead of vasodilation or infarct size reduction was observed [152].

These results from preclinical studies were confirmed in clinical observations in which SNP reduced the mean arterial blood pressure and led to improvements in CBF in patients after acute stroke $[158,159]$.

The mechanism of the neuroprotective action of $\mathrm{NO}^{\bullet}$ donors includes their abilities to reduce oxidative stress both in the brain and blood, inhibit the expression and activities of MMPs, scavenge $\mathrm{NO}^{\bullet}$ or quench ROS, reduce inflammation, exert antiplatelet effects and attenuate I/R-mediated increases in ICAM-1 and E-selectin mRNA expression [160,161].

Suppression of the hydrolysis of L-arginine into ornithine and urea by arginases increased the production of $\mathrm{NO}^{\bullet}$ and prevented the development of endothelial dysfunction [162], similar to the effects of eliminating asymmetric dimethylarginine (ADMA) endogenous NOS inhibitor, through the stimulation of ADMA-hydrolyzing enzyme (DDAH II) [163].

The available data concerning the efficacy of the enhancement of $\mathrm{NO}^{\bullet}$ productionbased therapies are collected in Table 1.

\subsection{NOS Inhibitors}

Selective inhibition of nNOS and iNOS activities is thought to counteract the aftermath of stroke.

The neuroprotective abilities of N( $\omega)$-nitro-L-arginine methyl ester (L-NAME) and 7-nitroindazole (7-NI), widely used NOS/nNOS inhibitors, are time-dependent and are observed in the early stages of ischemic insult [164]. The choice of dose is important, as the compounds prevent at low doses but potentiate ischemia-induced neurodegeneration at high doses [165]. Long-term inhibition of NOS might be too risky because of the off-target effects on eNOS, particularly in patients with cardiovascular risk or metabolic diseases.

Direct or indirect inhibition of iNOS through selective inhibitors, such as aminoguanidine (AG) or the $\mathrm{BH}_{4}$ rate-limiting enzyme GTP cyclohydrolase I, attenuated cerebral infarction, ischemia-induced pathologies and prevented the progression of cerebral aneurysms [166-168].

The available data concerning the efficacy of NOS inhibitor-based therapies are collected in Table 1. For review please see also: [164]. 
Table 1. Enhancement of NO• production and NOS inhibitor-based therapies. Pretreatment indicates that the compound was administered before experimental ischemia; posttreatment indicates that the compound was administered after the episode. MCAO—middle cerebral artery occlusion, ODG—oxygen and glucose deprivation.

\begin{tabular}{|c|c|c|c|}
\hline & Compound & Effect & \\
\hline \multicolumn{4}{|l|}{ NO Donors } \\
\hline \multirow[t]{17}{*}{ Pretreatment } & LA-419 & in vivo: & {$[156,157]$} \\
\hline & & $\begin{array}{l}\text { - } \text { reduced iNOS, nNOS, nitrotyrosine expression and increased } \\
\text { apparent diffusion coefficient in endothelin-1-induced focal } \\
\text { cerebral ischemia or global cerebral ischemia model in rats } \\
\text { induced by oxygen and glucose deprivation }\end{array}$ & \\
\hline & GSNO & 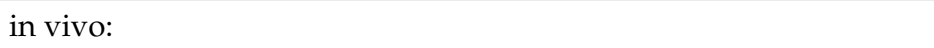 & [169-172] \\
\hline & & 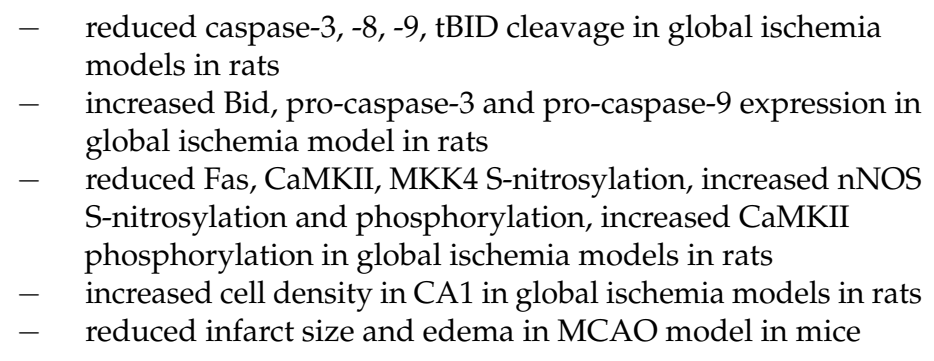 & \\
\hline & ZJM-289 & $\begin{array}{l}\text { in vitro: } \\
-\quad \text { increased cell viability in primary cortical neuron in OGD } \\
\text { model } \\
-\quad \text { reduced mitochondrial dysfunction in primary cortical } \\
\text { neuron in OGD model } \\
-\quad \text { decreased } \mathrm{Ca}^{2+} \text { release and ROS production in primary } \\
\text { in vivo? }\end{array}$ & {$[155,173]$} \\
\hline & & $\begin{array}{l}\text { - } \begin{array}{l}\text { reduced infarct size and edema and improved neurologic } \\
\text { deficit in MCAO model in rats }\end{array}\end{array}$ & \\
\hline & SIN-1 & in vivo: & {$[174,175]$} \\
\hline & & - $\quad$ no influence or reduced infarct size in MCAO model in rats & \\
\hline & DETA NONOate & in vivo: & [174] \\
\hline & & - $\quad$ no influence on infarct size in MCAO model in rats & \\
\hline & NBP & in vitro: & {$[173,176]$} \\
\hline & & $\begin{array}{l}\text { - } \quad \text { increased cell viability in primary cortical neuron in OGD } \\
\text { model } \\
\text { - } \quad \text { reduced mitochondrial dysfunction in primary cortical } \\
\text { neuron in OGD model } \\
-\quad \text { decreased } \mathrm{Ca}^{2+} \text { release and ROS production in primary } \\
\text { in vivo? }\end{array}$ & \\
\hline & & $\begin{array}{l}\text { - } \text { reduced infarct size and improved neurologic deficit in } \\
\text { MCAO model in rats }\end{array}$ & \\
\hline & Spermine NONOate & in vivo: & [152] \\
\hline & & $\begin{array}{ll}- & \text { reduced infarct size in MCAO model in rats } \\
- & \text { increased cortical perfusion in MCAO model in rats }\end{array}$ & \\
\hline & sodium nitroprusside & in vivo: & [152] \\
\hline & & - $\quad$ reduced infarct size in MCAO model in rats & \\
\hline
\end{tabular}


Table 1. Cont.

\begin{tabular}{|c|c|c|c|}
\hline & Compound & Effect & \\
\hline \multicolumn{4}{|l|}{ NO Donors } \\
\hline \multirow[t]{8}{*}{ Posttreatment } & GSNO & in vivo: & {$[171]$} \\
\hline & & - $\quad$ reduced infarct size & \\
\hline & DETA NONOate & in vivo: & [150] \\
\hline & & $\begin{array}{l}\text { - } \quad \text { no influence on infarct size in MCAO model in rats } \\
\text { - } \quad \text { improved neurologic deficit and increased cGMP level in } \\
\text { MCAO model in rats } \\
\text { - } \\
\text { increased cell proliferation in subventricular zone, olfactory } \\
\text { bulb and dentate gyrus in MCAO model in rats }\end{array}$ & \\
\hline & SIN-1 & in vivo: & {$[153,154]$} \\
\hline & & - $\quad$ reduced infarct size in $\mathrm{MCAO}$ model in rats & \\
\hline & sodium nitroprusside & in vivo: & [153] \\
\hline & & - $\quad$ reduced infarct size in MCAO model in rats & \\
\hline \multicolumn{4}{|l|}{$\begin{array}{l}\text { NOS or nNOS } \\
\text { inhibitors }\end{array}$} \\
\hline \multirow[t]{4}{*}{ Pretreatment } & 7-NI & in vivo: & {$[170,172,177]$} \\
\hline & & $\begin{array}{l}\text { - } \quad \text { increased nNOS S-nitrosylation and phosphorylation, } \\
\text { decreased CaMKII and MKK4 S-nitrosylation and increased } \\
\text { CaMKII phosphorylation in global ischemia model or MCAO } \\
\text { in rats } \\
\text { - } \quad \text { decreased caspase-3 cleavage in MCAO model in rats } \\
\text { - } \\
\text { increased cell density in CA1 in global ischemia model or } \\
\text { MCAO model in rats } \\
\text { - } \\
\text { reduced maximal NO concentration in bilateral common } \\
\text { carotid artery occlusion in rats }\end{array}$ & \\
\hline & L-NAME & in vivo: & {$[174,178]$} \\
\hline & & $\begin{array}{l}\text { - } \quad \text { reduced infarct size and improved neurological deficit in } \\
\text { MCAO model in rats } \\
\text { - } \\
\text { reduced glutamate, aspartate, glutamine synthetase and } \\
\text { nitrate/nitrite level in MCAO model in rats } \\
\text { - } \quad \text { increased ATP and NAD level in MCAO model in rats } \\
\text { - } \quad \text { reduced TNF- } \alpha \text { expression and increased IL-10 expression in } \\
\text { MCAO model in rats }\end{array}$ & \\
\hline \multirow[t]{4}{*}{ Posttreatment } & 7-NI & in vivo: & [179] \\
\hline & & - $\quad$ reduced neuronal damage in global cerebra ischemia in rats & \\
\hline & L-NAME & in vivo: & {$[178,180]$} \\
\hline & & $\begin{array}{l}\text { - } \begin{array}{l}\text { reduced infarct volume in MCAO model in rats and mice } \\
\text { - }\end{array} \text { improved neurological deficit in MCAO model in rats and } \\
\text { mice } \\
\text { - } \\
\text { reduced level of tissue nitric oxide end products in MCAO } \\
\text { model in mice } \\
\text { reduced nitrate/nitrite level and increased NAD level in } \\
\text { MCAO model in rats }\end{array}$ & \\
\hline
\end{tabular}


Table 1. Cont.

\begin{tabular}{|c|c|c|c|}
\hline & Compound & Effect & \\
\hline \multicolumn{4}{|c|}{ iNOS inhibitors } \\
\hline \multirow[t]{2}{*}{ Pretreatment } & aminoguanidine & in vivo: & {$[181]$} \\
\hline & & $\begin{array}{l}\text { - reduced infarct volume, edema, neurological deficits, necrotic } \\
\text { cell death in penumbra and core and reduced apoptosis in } \\
\text { penumbra in MCAO model in rats }\end{array}$ & \\
\hline \multirow[t]{6}{*}{ Posttreatment } & aminoguanidine & in vivo: & {$[167,182,183]$} \\
\hline & & $\begin{array}{l}\text { - } \quad \text { reduced infarct volume in permanent } \mathrm{MCAO} \text { model in mice } \\
\text { - } \quad \text { reduced ischemia-induced neurogenesis in dentate gyrus in } \\
\text { MCAO model in rats }\end{array}$ & \\
\hline & $1400 \mathrm{~W}$ & in vivo: & {$[184]$} \\
\hline & & $\begin{array}{l}\text { - reduced infarct size neurological deficit in MCAO model in } \\
\text { rats } \\
\text { - inhibited delayed increase in glutamate level in MCAO model } \\
\text { in rats }\end{array}$ & \\
\hline & S-methylisothiorea & in vivo: & [185] \\
\hline & & $\begin{array}{l}\text { - } \text { reduced neurological deficit, mortality, infarct volume ratio in } \\
\text { MCAO model in rats } \\
\text { - } \quad \text { attenuated morphological changes in cortical neurons in } \\
\text { MCAO model in rats }\end{array}$ & \\
\hline
\end{tabular}

\subsection{HIF-1 $\alpha$}

HIF- $1 \alpha$ is an essential component in changing the transcriptional repertoire of tissues during oxygen deprivation and plays a pivotal role in the regulation of iNOS activity. Thus, HIF- $1 \alpha$ and the genes regulated by it have been the center of intense research. A growing number of pre-clinical studies in rodents suggests that the activation of HIF- $1 \alpha$ signaling pathway prior or shortly after ischemic stroke reduces tissue damage and increases functional recovery from ischemic stroke [87,96,186-189]. One example of an agent that stabilizes the transcriptional activator HIF- $1 \alpha$ and activates target genes involved in compensation for ischemia are inhibitors of HIF- $1 \alpha$ prolyl hydrolases (PHD1, PHD2 and PHD3) [190]. The beneficial effects of PHD inhibition after ischemia require the activity of HIF- $1 \alpha$ as shown in in vitro in oxygen glucose deprivation model of ischemia and in vivo in MCAO model in mice [96]. Dimethyloxalylglycine (DMOG) enhanced the activation of HIF- $1 \alpha$ and enhanced transcription of the HIF-regulated genes. In vivo the infarct size, activation of pro-apoptotic proteins and behavioral deficits after stroke were reduced. The effect of DMOG was decreased after inhibition of HIF- $1 \alpha$ with digoxin [96]. Similar effects were observed with small molecule hypoxia mimics, such as deferoxamine, cobalt chloride or GSNO. Additionally, these agents increased the expression of HIF- $1 \alpha$ target genes $[92,93,191]$. Cocaine, andrographolide or vitamin E activated the HIF-VEGF pathway, thus increasing microvascular density, restoring local blood flow and protecting the brain from ischemic insults [192-194]. However, available data indicate that sustained and prolonged activation of the HIF- $1 \alpha$ pathway may lead to a transition from neuroprotection to neurodegeneration, reflecting the dual features of the HIF system [195-197], which should be taken into consideration when considering therapy to modify HIF- $1 \alpha$. Some contradictory results indicated that inhibition of HIF- $1 \alpha$ improved brain function in ischemia-reperfusion brain injury-related disorders [105,198]. Inhibition of free radical formation, followed by inhibition of HIF- $1 \alpha$ activation, apoptosis formation, neutrophil activation and iNOS expression resulted in reduction in the infarct volume in ischemiareperfusion brain injury (MCAO model) in rats [105]. In rat model of transient MCAO the early inhibition of HIF- $1 \alpha$ by application of inhibitors or small interfering RNA reduced infarct size and BBB hyperpermeability, decreased mortality and improved neurological 
deficits through inhibition of HIF- $1 \alpha$ activity $[198,199]$. The studies of Hsiao et al. showed that the administration of PMC [105].

The therapeutic strategies might lead to pleiotropic activation of HIF signaling through all cell types in CNS, making it difficult to draw conclusions about the significance of the HIF signaling pathway in the treatment of ischemia-reperfusion injury. However, the stimulation of the non-ischemic penumbra regions to initiate HIF-1 $\alpha$ (e.g., by inhibition of PHD) and subsequent downstream induction of HIF- $1 \alpha$ mediated antiapoptotic, vascular and glycolytic metabolic changes before the area is enveloped by the spreading ischemia may be one of the proposed therapeutic HIF-dependent effect. Additionally, inhibition of endothelial HIF- $1 \alpha$ warrants further investigation as a therapeutic target for the treatment of stroke patients with diabetes [99]. Table 2.

The available data concerning the efficacy of HIF- $1 \alpha$-based therapies are collected in

Table 2. HIF-1 $\alpha$-based therapies. Pretreatment indicates that the compound was administered before experimental ischemia; posttreatment indicates that the compound was administered after the episode. MCAO-middle cerebral artery occlusion, ODG-oxygen and glucose deprivation.

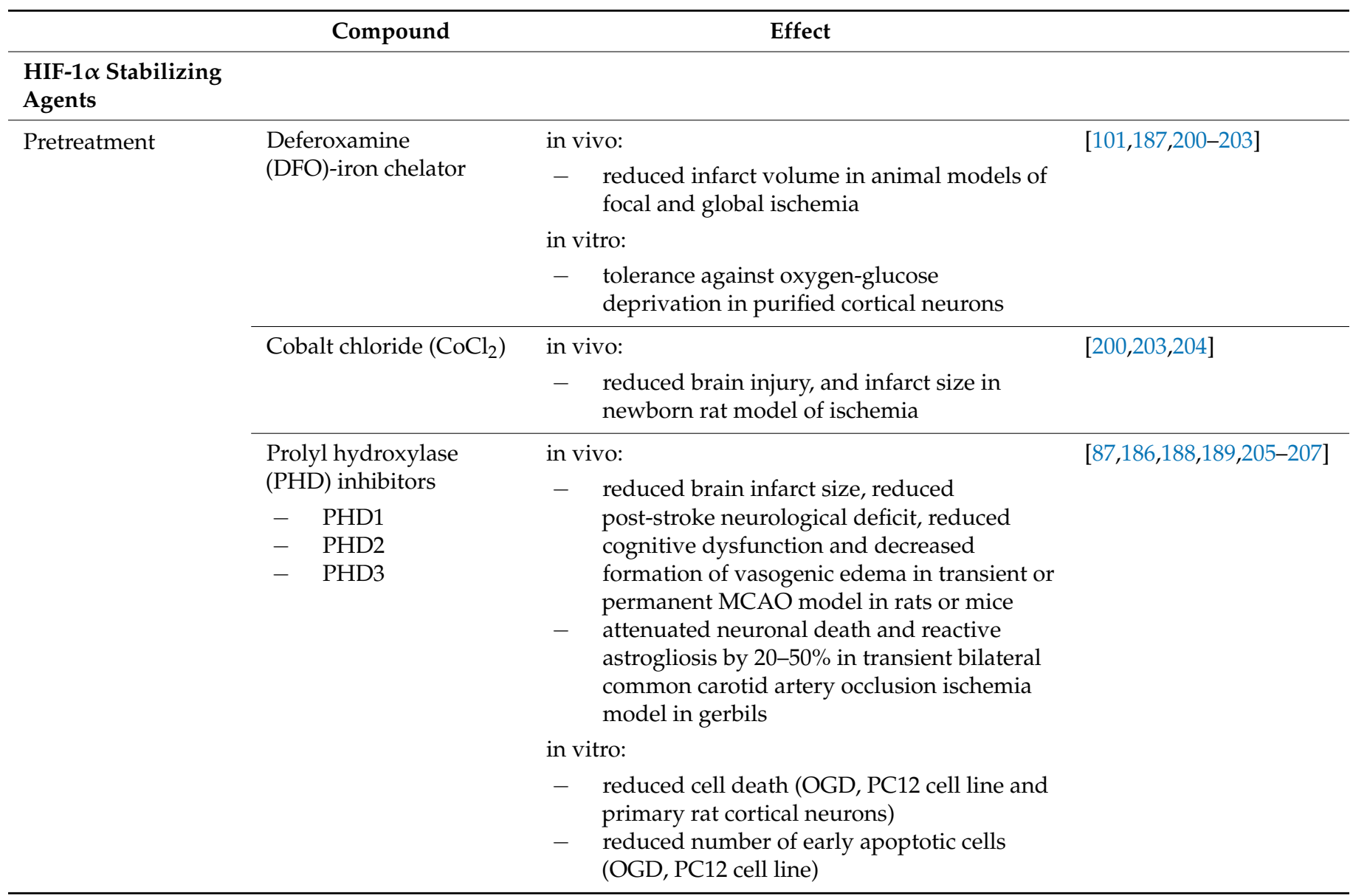


Table 2. Cont.

\begin{tabular}{|c|c|c|}
\hline & Compound & Effect \\
\hline \multicolumn{3}{|c|}{$\begin{array}{l}\text { HIF-1 } \alpha \text { Stabilizing } \\
\text { Agents }\end{array}$} \\
\hline Posttreatment & $\begin{array}{l}\text { Prolyl hydroxylase } \\
\text { inhibitors } \\
-\quad \text { PHD1 } \\
-\quad \text { PHD2 } \\
-\quad \text { PHD3 }\end{array}$ & $\begin{array}{l}\text { in vivo: } \\
\text { _ } \quad \text { reduced brain infarct size in MCAO model in } \\
\text { rats } \\
\text { - } \quad \text { attenuated neuronal death and reactive } \\
\text { astrogliosis by } 20-50 \% \text { in transient bilateral } \\
\text { common carotid artery occlusion ischemia } \\
\text { model in gerbils } \\
\text { in vitro: } \\
\text { - } \\
\text { stabilized HIF-1 } \alpha \text { and up-regulated HIF-1 } \\
\text { dependent target genes in primary murine } \\
\text { astrocytes and murine cerebrovascular } \\
\text { endothelial cell line (bEnd.3) in normal } \\
\text { conditions } \\
\text { protective effects in oxygen-glucose } \\
\text { deprivation in mouse hippocampal neuronal } \\
\text { HT-22 cell line }\end{array}$ \\
\hline
\end{tabular}

\section{HIF-1 $\alpha$ dependent} proteins

$\begin{array}{ll}\text { Pretreatment } \quad \text { Erythropoietin (EPO) } & \text { in vivo: } \\ & -\quad \text { protection against ischemia-induced cell } \\ & \text { death in bilateral common carotid artery } \\ & \text { occlusion in gerbils } \\ & -\quad \begin{array}{l}\text { reduction of infarct volume in permanent } \\ \text { MCAO model in mice or transient MCAO } \\ \text { model in rats }\end{array} \\ \end{array}$

- neuroprotective effect in transient MCAO model in rats up to $6 \mathrm{~h}$ posttreatment

- enhancement of neuronal survival in stroke-prone hypertensive rats after permanent MCAO

- enhancement of angiogenic responses in rat model of neonatal ischemia (permanent right CCAO)

- reduced perihematomal inflammation and apoptosis, induced functional recovery and upregulation of eNOS, STAT3, ERK in intracerebral hemorrhage model in rats in vitro:

- $\quad$ reduced NMDA-induced excitotoxicity in primary cortical neurons

- $\quad$ reduced cell death after hypoxia in rat primary hippocampal neurons

Vascular endothelial growth factor (VEGF) in vivo:

- reduced infarct size, enhanced neurogenesis, angiogenesis, cerebral microvascular perfusion and neurological dysfunction in $\mathrm{MCAO}$ and focal cerebral embolic ischemia in rats 
Table 2. Cont.

\begin{tabular}{l} 
\\
\hline Direct and indirect \\
HIF-1 $\alpha$ inhibitors
\end{tabular}

Compound

Effect

HIF-1 $\alpha$ inhibitors

Pretreatment

\begin{tabular}{|c|c|}
\hline Acriflavine & in vivo: \\
\hline & 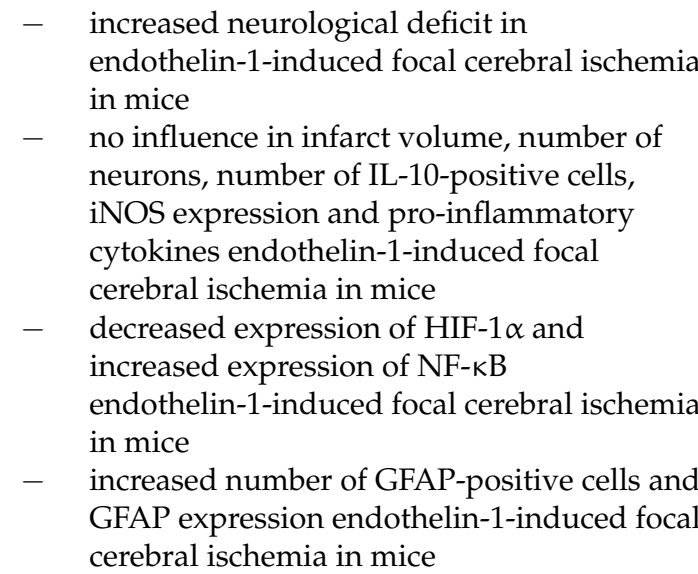 \\
\hline
\end{tabular}

\begin{tabular}{lll}
\hline 2,2,5,7,8-Pentamethyl-6- & in vivo: & [105] \\
hydroxychromane & $-\quad$ reduced infarct volume in MCAO model in \\
(PMC) & rats \\
& $-\quad$ reduced caspase-3 activation, reduced \\
& HIF-1 $\alpha$, iNOS and nitrotyrosine expression \\
& in MCAO model in rats
\end{tabular}

YC-1 in vivo:

- $\quad$ reduced HIF-1 $\alpha$, VEGF, EPO and GLUT-3 expression in MCAO model in rats

- increased mortality, infarct size and edema in MCAO model in rats

- reduced BBB permeability in MCAO model in rats

- $\quad$ reduced oxidative stress biomarkers in hippocampus in bilateral carotid artery occlusion in rats

- reduced TNF- $\alpha$, IL-6, BAX and Hsp90 level in hippocampus in bilateral carotid artery occlusion in rats

- increased IL-10 and Bcl-2 level in hippocampus in bilateral carotid artery occlusion in rats

- increased aspartate and glutamate level in hippocampus in bilateral carotid artery occlusion in rats

- reduced infarct volume and neurological deficit in MCAO model in mice

- reduced SOD activity and malondialdehyde level in MCAO model in mice

- reduced number iNOS-, COX2- and NF-kB-positive cells and their protein expression in MCAO model in mice

- reduced number of GFAP- and Iba-1-positive cells in MCAO model in mice 
Table 2. Cont.

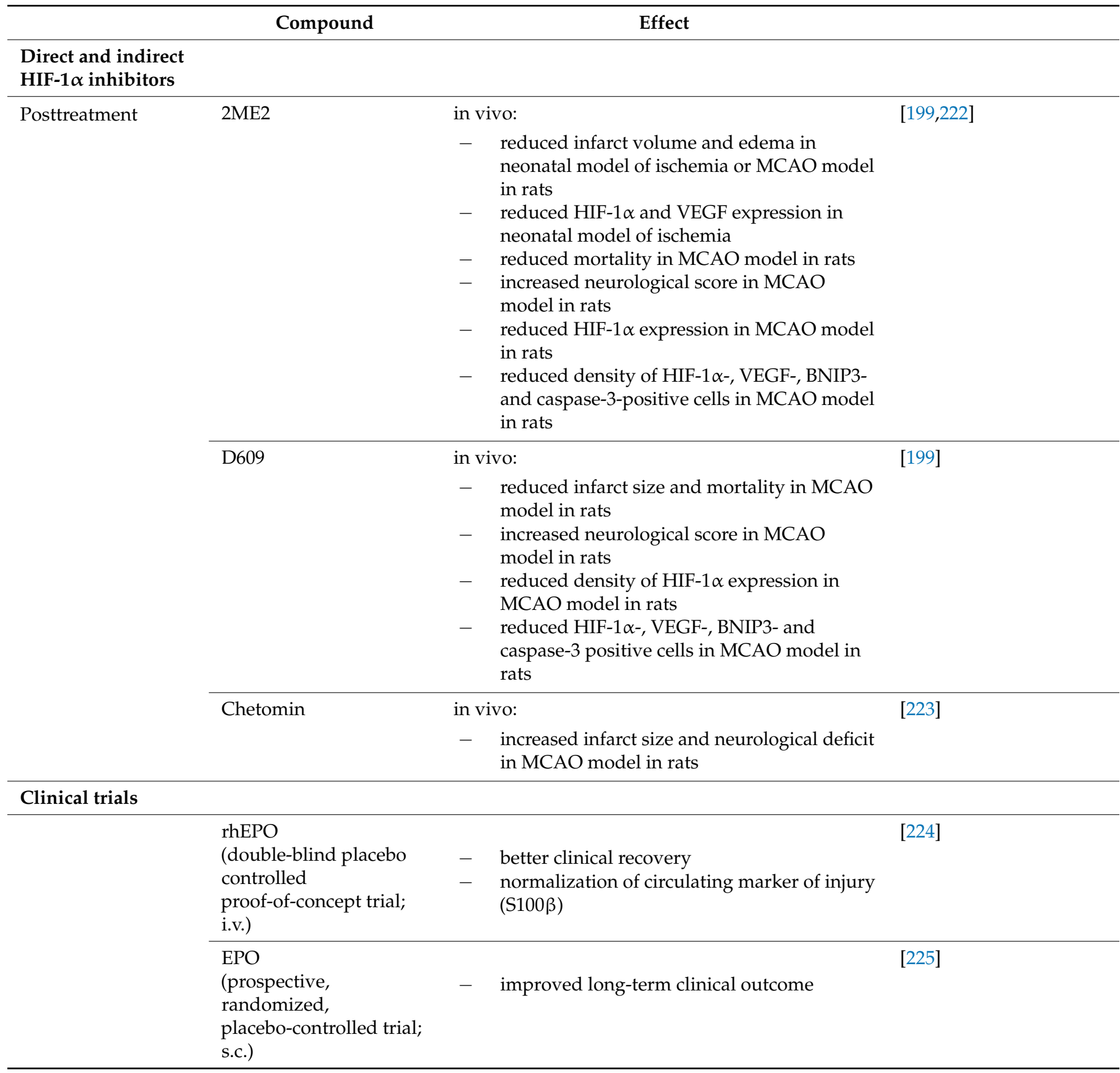

\subsection{Combination Therapies}

At present, it seems that combination therapies are more effective for treating stroke than monotherapies. Scavenging reactive oxygen species and concomitantly inhibiting $\mathrm{NO}$ 'synthesis by administering statins with resveratrol, an approved antioxidant or with nifedipine, a calcium channel blocker, is just one example of combination therapy for stroke [226]. Administration of resveratrol upregulated antioxidant enzyme activities, decreased $\mathrm{O}_{2}{ }^{\bullet-}$ production by downregulating NADPH oxidase activity and attenuated oxidative stress-mediated eNOS uncoupling. Some hope may be placed in combination therapy, which could allow minimization of the dose of NMDA antagonists by administering a compound enhancing its effect, such as caffeine [227] or cordycepin (an adenosine analog) [228]. The use of different agents at the same time enables avoidance of detrimental consequences induced by undesired side effects and reinforcement of beneficial impacts by 
mutual action. The examples of effective combined treatment therapies in clinical trials are collected in Table 3.

Table 3. Combined treatment therapies with the use of NO-related compounds in clinical trials. SOC—standard of care.

\begin{tabular}{|c|c|c|c|}
\hline Mode of Action & Combined Treatment & Effect & \\
\hline \multirow[t]{3}{*}{ Free radical scavenger } & $\begin{array}{l}\text { Edaravone }+ \text { Hyperbaric oxygen }+ \\
\text { Heparin } \\
\text { (pilot trial) }\end{array}$ & $\begin{array}{ll}\text { - } & \text { reduction of neurological } \\
\text { symptoms (NIHSS) }\end{array}$ & [229] \\
\hline & $\begin{array}{l}\text { Edaravone + t-PA } \\
\text { (pilot trial) }\end{array}$ & $\begin{array}{ll}- & \text { early recanalization } \\
- & \text { higher percent of remarkable } \\
& \text { recovery }(\geq 8 \text {-point reduction on } \\
\text { NIHSS) }\end{array}$ & [230] \\
\hline & $\begin{array}{l}\text { Edaravone }+\mathrm{t}-\mathrm{PA} \\
\text { (multicenter, prospective, randomized } \\
\text { and open-label trial) }\end{array}$ & $\begin{array}{l}\text { no effect on the rate of early } \\
\text { recanalization, symptomatic } \\
\text { intracerebral hemorrhage or } \\
\text { favorable outcome after tPA } \\
\text { therapy }\end{array}$ & [231] \\
\hline $\begin{array}{l}\text { NMDA antagonist, VGSC and } \\
\text { VGCC blocker, inhibitor of NO } \\
\text { synthesis }\end{array}$ & $\begin{array}{l}\text { Lubeluzole }+ \text { t-PA } \\
\text { (feasibility, safety and efficacy } \\
\text { trial-uncompleted) }\end{array}$ & $\begin{array}{l}\text { study was terminated after } \\
\text { Lubeluzole's phase III trial showed } \\
\text { no overall improvement }\end{array}$ & [232] \\
\hline Statin & $\begin{array}{l}\text { Simvastatin + t-PA } \\
\text { (phase IV, prospective, randomized, } \\
\text { double-blind, placebo-controlled trial) }\end{array}$ & $\begin{array}{l}\text { higher proportion of patients } \\
\text { undergo major neurological } \\
\text { recovery (post hoc analysis) }\end{array}$ & [233] \\
\hline $\begin{array}{l}\text { Typical antipsychotic } \\
+ \text { First-generation antihistamine }\end{array}$ & $\begin{array}{l}\text { Chlorpromazine }+ \text { Promethazine }+ \text { SOC } \\
\text { (pilot trial) }\end{array}$ & $\begin{array}{ll}\text { - } & \text { no effect on neurological symptoms } \\
\text { (NIHSS, mRS) }\end{array}$ & [234] \\
\hline
\end{tabular}

\section{Conclusions}

Stroke is one of the most common indications with unmet medical needs in medicine, and it is a major challenge to develop effective treatments, as stroke treatments need to reduce cell death and infarct size, stabilize the blood-brain barrier, reduce reoxygenationinduced leakage and preserve neuromotor function in a supra-additive manner. The NO ${ }^{\bullet}$ dependent pathway plays a crucial role in all processes involved in subsequent events after ischemia $[49,154,235]$. However, $\mathrm{NO}^{\bullet}$-based treatments can be burdened with a variety of adverse effects. The risk of exacerbating pathological changes with $\mathrm{NO}^{\bullet}$-regulating agents is also high. The objective is to restore the imbalance L-arginine/ADMA-NOS-NO ${ }^{\bullet}$ [236] and protect against hypoxic/ischemic-derived damage.

The use of combined treatment therapies seems to be the best alternative. The number of plausible combinations is almost unlimited. The only limitation is the satisfactory effectiveness and the lack of the induction of adverse effects. The challenge is to find satisfactory solution. $\mathrm{NO}^{\bullet}$-related pathways and the agents that inhibit excess of $\mathrm{NO}^{\bullet}$ production especially of that which comes from nNOS or iNOS, free radicals' scavengers or compounds targeting HIF- $1 \alpha$ give a number of possibilities that still have not been fully investigated so far. The vast range of studies discussed in the present review and by others indicates, that the area is still open for investigation.

Author Contributions: All the authors equally contributed to manuscript preparation and writing. All authors have read and agreed to the published version of the manuscript.

Funding: Grants no 2019/33/B/NZ7/02699 (OPUS 17, National Science Center) and no DIR/WK/2017/01 (Ministry of Science and Higher Education Poland).

Acknowledgments: The authors would like to thank Studio Grafiki i Komiksu studiokomiks.pl (Krzysztof Czachura) Design for graphical support in preparation of the figures.

Conflicts of Interest: The authors declare no conflict of interest. 


\section{References}

1. GBD 2019 Diseases and Injuries Collaborators. Global burden of 369 diseases and injuries in 204 countries and territories, 1990-2019: A systematic analysis for the Global Burden of Disease Study 2019. Lancet 2020, 396, 1204-1222. [CrossRef]

2. GBD 2016 Causes of Death Collaborators. Global, regional, and national age-sex specific mortality for 264 causes of death, 1980-2016: A systematic analysis for the Global Burden of Disease Study 2016. Lancet 2017, 390, 1151-1210. [CrossRef]

3. Müller, G.J.; Stadelmann, C.; Bastholm, L.; Elling, F.; Lassmann, H.; Johansen, F.F. Ischemia leads to apoptosis-and necrosis-like neuron death in the ischemic rat hippocampus. Brain Pathol. 2004, 14, 415-424. [CrossRef]

4. Aarts, M.; Liu, Y.; Liu, L.; Besshoh, S.; Arundine, M.; Gurd, J.W.; Wang, Y.-T.; Salter, M.W.; Tymianski, M. Treatment of ischemic brain damage by perturbing NMDA receptor- PSD-95 protein interactions. Science 2002, 298, 846-850. [CrossRef]

5. Zhang, S.J.; Steijaert, M.N.; Lau, D.; Schutz, G.; Delucinge-Vivier, C.; Descombes, P.; Bading, H. Decoding NMDA receptor signaling: Identification of genomic programs specifying neuronal survival and death. Neuron 2007, 53, 549-562. [CrossRef]

6. Christopherson, K.S.; Hillier, B.J.; Lim, W.A.; Bredt, D.S. PSD-95 assembles a ternary complex with the N-methyl-D-aspartic acid receptor and a bivalent neuronal NO synthase PDZ domain. J. Biol. Chem. 1999, 274, 27467-27473. [CrossRef]

7. Palmer, R.M.; Rees, D.D.; Ashton, D.S.; Moncada, S. L-arginine is the physiological precursor for the formation of nitric oxide in endothelium-dependent relaxation. Biochem. Biophys. Res. Commun. 1988, 153, 1251-1256. [CrossRef]

8. Katsuki, S.; Arnold, W.; Mittal, C.; Murad, F. Stimulation of guanylate cyclase by sodium nitroprusside, nitroglycerin and nitric oxide in various tissue preparations and comparison to the effects of sodium azide and hydroxylamine. J. Cyclic Nucleotide Res. 1977, 3, 23-35. [PubMed]

9. Miki, N.; Kawabe, Y.; Kuriyama, K. Activation of cerebral guanylate cyclase by nitric oxide. Biochem. Biophys. Res. Commun. 1977, 75, 851-856. [CrossRef]

10. Bon, C.L.M.; Garthwaite, J. On the role of nitric oxide in hippocampal long-term potentiation. J. Neurosci. 2003, 23, 1941-1948. [CrossRef]

11. Kalinowski, L.; Malinski, T. Endothelial NADH/NADPH-dependent enzymatic sources of superoxide production: Relationship to endothelial dysfunction. Acta Biochim. Pol. 2004, 51, 459-469. [CrossRef] [PubMed]

12. Leone, A.M.; Palmer, R.M.; Knowles, R.G.; Francis, P.L.; Ashton, D.S.; Moncada, S. Constitutive and inducible nitric oxide synthases incorporate molecular oxygen into both nitric oxide and citrulline. J. Biol. Chem. 1991, 266, 23790-23795. [CrossRef]

13. Lelchuk, R.; Radomski, M.W.; Martin, J.F.; Moncada, S. Constitutive and inducible nitric oxide synthases in human megakaryoblastic cells. J. Pharmacol. Exp. Ther. 1992, 262, 1220-1224.

14. Eliasson, M.J.; Huang, Z.; Ferrante, R.J.; Sasamata, M.; Molliver, M.E.; Snyder, S.H.; Moskowitz, M.A. Neuronal nitric oxide synthase activation and peroxynitriteformation in ischemic stroke linked to neural damage. J. Neurosci. 1999, 19, 5910-5918. [CrossRef] [PubMed]

15. Xia, Y.; Zweier, J.L. Superoxide and peroxynitrite generation from inducible nitric oxide synthase in macrophages. Proc. Natl. Acad. Sci. USA 1997, 94, 6954-6958. [CrossRef] [PubMed]

16. Pellegrini-Giampietro, D.E.; Cherici, G.; Alesiani, M.; Carlà, V.; Moroni, F. Excitatory amino acid release from rat hippocampal slices as a consequence of free-radical formation. J. Neurochem. 1988, 51, 1960-1963. [CrossRef] [PubMed]

17. Raghavan, S.; Dikshit, M. Vascular regulation by the L-arginine metabolites, nitric oxide and agmatine. Pharmacol. Res. 2004, 49, 397-414. [CrossRef]

18. Dereski, M.O.; Chopp, M.; Knight, R.A.; Rodolosi, L.C.; Garcia, J.H. The heterogeneous temporal evolution of focal ischemic neuronal damage in the rat. Acta Neuropathol. 1993, 85, 327-333. [CrossRef]

19. Ginsberg, M.D.; Busto, R. Rodent models of cerebral ischemia. Stroke 1989, 20, 1627-1642. [CrossRef] [PubMed]

20. Samdani, A.F.; Dawson, T.M.; Dawson, V.L. Nitric oxide synthase in models of focal ischemia. Stroke 1997, $28,1283-1288$. [CrossRef]

21. Garry, P.S.; Ezra, M.; Rowland, M.J.; Westbrook, J.; Pattinson, K.T.S. The role of the nitric oxide pathway in brain injury and its treatment-From bench to bedside. Exp. Neurol. 2015, 263, 235-243. [CrossRef]

22. Bolaños, J.P.; Almeida, A. Roles of nitric oxide in brain hypoxia-ischemia. Biochim. Biophys. Acta 1999, 1411, 415-436. [CrossRef]

23. Dirnagl, U.; Iadecola, C.; Moskowitz, M.A. Pathobiology of ischaemic stroke: An integrated view. Trends Neurosci. 1999, 22, 391-397. [CrossRef]

24. Chen, Z.-Q.; Mou, R.-T.; Feng, D.-X.; Wang, Z.; Chen, G. The role of nitric oxide in stroke. Med. Gas Res. 2017, 7, 194-203. [CrossRef]

25. Heiss, W.D. Experimental evidence of ischemic thresholds and functional recovery. Stroke 1992, 23, 1668-1672. [CrossRef] [PubMed]

26. Furlan, M.; Marchal, G.; Viader, F.; Derlon, J.M.; Baron, J.C. Spontaneous neurological recovery after stroke and the fate of the ischemic penumbra. Ann. Neurol. 1996, 40, 216-226. [CrossRef]

27. Baird, A.E.; Benfield, A.; Schlaug, G.; Siewert, B.; Lövblad, K.O.; Edelman, R.R.; Warach, S. Enlargement of human cerebral ischemic lesion volumes measured by diffusion-weighted magnetic resonance imaging. Ann. Neurol. 1997, 41, 581-589. [CrossRef]

28. Castillo, J.; Rama, R.; Dávalos, A. Nitric oxide-related brain damage in acute ischemic stroke. Stroke 2000, 31, 852-857. [CrossRef]

29. Forster, C.; Clark, H.B.; Ross, M.E.; Iadecola, C. Inducible nitric oxide synthase expression in human cerebral infarcts. Acta Neuropathol. 1999, 97, 215-220. [CrossRef] 
30. Ketheeswaranathan, P.; Turner, N.A.; Spary, E.J.; Batten, T.F.C.; McColl, B.W.; Saha, S. Changes in glutamate transporter expression in mouse forebrain areas following focal ischemia. Brain Res. 2011, 1418, 93-103. [CrossRef]

31. Mayhan, W.G.; Didion, S.P. Glutamate-induced disruption of the blood-brain barrier in rats. Role of nitric oxide. Stroke 1996, 27, 965-970. [CrossRef] [PubMed]

32. Zhou, L.; Zhu, D.Y. Neuronal nitric oxide synthase: Structure, subcellular localization, regulation, and clinical implications. Nitric Oxide Biol. Chem. 2009, 20, 223-230. [CrossRef] [PubMed]

33. Fabian, R.H.; Perez-Polo, J.R.; Kent, T.A. Perivascular nitric oxide and superoxide in neonatal cerebral hypoxia-ischemia. Am. J. Physiol. Heart Circ. Physiol. 2008, 295, H1809-H1814. [CrossRef] [PubMed]

34. Onodera, H.; Kogure, K.; Ono, Y.; Igarashi, K.; Kiyota, Y.; Nagaoka, A. Proto-oncogene c-fos is transiently induced in the rat cerebral cortex after forebrain ischemia. Neurosci. Lett. 1989, 98, 101-104. [CrossRef]

35. Wessel, T.C.; Joh, T.H.; Volpe, B.T. In situ hybridization analysis of c-fos and c-jun expression in the rat brain following transient forebrain ischemia. Brain Res. 1991, 567, 231-240. [CrossRef]

36. Jiang, X.; Mu, D.; Manabat, C.; Koshy, A.A.; Christen, S.; Täuber, M.G.; Vexler, Z.S.; Ferriero, D.M. Differential vulnerability of immature murinae neurons to oxygen-glucose deprivation. Exp. Neurol. 2004, 190, 224-232. [CrossRef]

37. Grima, G.; Benz, B.; Do, K.Q. Glial-derived arginine, the nitric oxide precursor, protects neurons from NMDA-induced excitotoxicity. Eur. J. Neurosci. 2001, 14, 1762-1770. [CrossRef]

38. Kondo, T.; Reaume, A.G.; Huang, T.T.; Carlson, E.; Murakami, K.; Chen, S.F.; Hoffman, E.K.; Scott, R.W.; Epstein, C.J.; Chan, P.H Reduction of $\mathrm{CuZn}$-superoxide dismutase activity exacerbates neuronal cell injury and edema formation after transient focal cerebral ischemia. J. Neurosci. 1997, 17, 4180-4189. [CrossRef]

39. Kondo, T.; Reaume, A.G.; Huang, T.T.; Murakami, K.; Carlson, E.; Chen, S.; Scott, R.W.; Epstein, C.J.; Chan, P.H. Edema formation exacerbates neurological and histological outcomes after focal cerebral ischemia in CuZn-superoxide dismutase gene knockout mutant mice. Acta Neurochir. Suppl. 1997, 70, 62-64.

40. Chan, P.H.; Epstein, C.J.; Li, Y.; Huang, T.T.; Carlson, E.; Kinouchi, H.; Yang, G.; Kamii, H.; Mikawa, S.; Kondo, T.; et al. Transgenic mice and knockout mutants in the study of oxidative stress in brain injury. J. Neurotrauma 1995, 12, 815-824. [CrossRef]

41. Léveillé, F.; Gaamouch, F.E.; Gouix, E.; Lecocq, M.; Lobner, D.; Nicole, O.; Buisson, A. Neuronal viability is controlled by a functional relation between synaptic and extrasynaptic NMDA receptors. FASEB J. 2008, 22, 4258-4271. [CrossRef] [PubMed]

42. Singh, P.; Doshi, S.; Spaethling, J.M.; Hockenberry, A.J.; Patel, T.P.; Geddes-Klein, D.M.; Lync, D.R.; Meaney, D.F. N-methyl-Daspartate receptor mechanosensitivity is governed by C terminus of NR2B subunit. J. Biol. Chem. 2012, 287, 4348-4359. [CrossRef] [PubMed]

43. Maneshi, M.M.; Maki, B.; Gnanasambandam, R.; Belin, S.; Popescu, G.K.; Sachs, F.; Hua, S.Z. Mechanical stress activates NMDA receptors in the absence of agonists. Sci. Rep. 2017, 7, 39610. [CrossRef]

44. Amorini, A.M.; Lazzarino, G.; Pietro, V.D.; Signoretti, S.; Lazzarino, G.; Belli, A.; Tavazzi, B. Severity of experimental traumatic brain injury modulates changes in concentrations of cerebral free amino acids. J. Cell. Mol. Med. 2017, 21, 530-542. [CrossRef] [PubMed]

45. Palmer, A.M.; Marion, D.W.; Botscheller, M.L.; Bowen, D.M.; DeKosky, S.T. Increased transmitter amino acid concentration in human ventricular CSF after brain trauma. Neuroreport 1994, 6, 153-156. [CrossRef]

46. Ito, Y.; Ohkubo, T.; Asano, Y.; Hattori, K.; Shimazu, T.; Yamazato, M.; Nagoya, H.; Kato, Y.; Araki, N. Nitric oxide production during cerebral ischemia and reperfusion in eNOS- and nNOS-knockout mice. Curr. Neurovasc. Res. 2010, 7, 23-31. [CrossRef]

47. Wei, G.; Dawson, V.L.; Zweier, J.L. Role of neuronal and endothelial nitric oxide synthase in nitric oxide generation in the brain following cerebral ischemia. Biochim. Biophys. Acta 1999, 1455, 23-34. [CrossRef]

48. Cui, X.; Chopp, M.; Zacharek, A.; Zhang, C.; Roberts, C.; Chen, J. Role of endothelial nitric oxide synthetase in arteriogenesis after stroke in mice. Neuroscience 2009, 159, 744-750. [CrossRef] [PubMed]

49. Huang, Z.; Huang, P.L.; Ma, J.; Meng, W.; Ayata, C.; Fishman, M.C.; Moskowitz, M.A. Enlarged infarcts in endothelial nitric oxide synthase knockout mice are attenuated by nitro-L-arginine. J. Cereb. Blood Flow Metab. 1996, 16, 981-987. [CrossRef]

50. Jiang, Z.; Li, C.; Arrick, D.M.; Yang, S.; Baluna, A.E.; Sun, H. Role of nitric oxide synthases in early blood-brain barrier disruption following transient focal cerebral ischemia. PLoS ONE 2014, 9, e93134. [CrossRef] [PubMed]

51. Zarruk, J.G.; Greenhalgh, A.D.; David, S. Microglia and macrophages differ in their inflammatory profile after permanent brain ischemia. Exp. Neurol. 2018, 301, 120-132. [CrossRef]

52. Pei, X.; Li, Y.; Zhu, L.; Zhou, Z. Astrocyte-derived exosomes suppress autophagy and ameliorate neuronal damage in experimental ischemic stroke. Exp. Cell Res. 2019, 382, 111474. [CrossRef] [PubMed]

53. Stanimirovic, D.B.; Wong, J.; Shapiro, A.; Durkin, J.P. Increase in surface expression of ICAM-1, VCAM-1 and E-selectin in human cerebromicrovascular endothelial cells subjected to ischemia-like insults. Acta Neurochir. Suppl. 1997, 70, 12-16. [CrossRef]

54. Wilhelmsson, U.; Bushong, E.A.; Price, D.L.; Smarr, B.L.; Phung, V.; Terada, M.; Ellisman, M.H.; Pekny, M. Redefining the concept of reactive astrocytes as cells that remain within their unique do-mains upon reaction to injury. Proc. Natl. Acad. Sci. USA 2006, 103, 17513-17518. [CrossRef] [PubMed]

55. Liddelow, S.A.; Guttenplan, K.A.; Clarke, L.E.; Bennett, F.C.; Bohlen, C.J.; Schirmer, L.; Bennett, M.L.; Münch, A.E.; Chung, W.-S.; Peterson, T.C.; et al. Neurotoxic reactive astrocytes are induced by activated microglia. Nature 2017, 541, 481-487. [CrossRef]

56. Buskila, Y.; Farkash, S.; Hershfinkel, M.; Amitai, Y. Rapid and reactive nitric oxide production by astrocytes in mouse neocortical slices. Glia 2005, 52, 169-176. [CrossRef] 
57. Zhao, S.-C.; Ma, L.-S.; Chu, Z.-H.; Xu, H.; Wu, W.-Q.; Liu, F. Regulation of microglial activation in stroke. Acta Pharmacol. Sin. 2017, 38, 445-458. [CrossRef]

58. Hewett, S.I.; Csernansky, C.A.; Choi, D.W. Selective potentiation of NMDA-induced neuronal injury following induction of astrocytic iNOS. Neuron 1994, 13, 487-494. [CrossRef]

59. Garcia-Bonilla, L.; Moore, J.M.; Racchumi, G.; Zhou, P.; Butler, J.M.; Iadecola, C.; Anrather, J. Inducible Nitric Oxide Synthase in Neutrophils and Endothelium Contributes to Ischemic Brain Injury in Mice. J. Immunol. 2014, 193, 2531-2537. [CrossRef]

60. Iadecola, C.; Zhang, F.; Xu, S.; Casey, R.; Ross, M.E. Inducible nitric oxide synthase gene expression in brain following cerebral ischemia. J. Cereb. Blood Flow Metab. 1995, 15, 378-384. [CrossRef] [PubMed]

61. Iadecola, C.; Zhang, F.; Casey, R.; Nagayama, M.; Ross, M.E. Delayed reduction of ischemic brain injury and neurological deficits in mice lacking the inducible nitric oxide synthase gene. J. Neurosci. 1997, 17, 9157-9164. [CrossRef] [PubMed]

62. Chan, P.H.; Schmidley, J.W.; Fishman, R.A.; Longar, S.M. Brain injury, edema, and vascular permeability changes induced by oxygen-derived free radicals. Neurology 1984, 34, 315-320. [CrossRef] [PubMed]

63. Gasche, Y.; Fujimura, M.; Morita-Fujimura, Y.; Copin, J.C.; Kawase, M.; Massengale, J.; Chan, P.H. Early appearance of activated matrix metalloproteinase-9 after focal cerebral ischemia in mice: A possible role in blood-brain barrier dysfunction. Int. Soc. Cereb. Blood Flow Metab. 1999, 19, 1020-1028. [CrossRef]

64. Guo, M.; Cox, B.; Mahale, S.; Davis, W.; Carranza, A.; Hayes, K.; Sprague, S.; Jimenez, D.; Ding, Y. Pre-ischemic exercise reduces matrix metalloproteinase-9 expression and ameliorates blood-brain barrier dysfunction in stroke. Neuroscience 2008, 151, 340-351. [CrossRef]

65. Broughton, B.R.S.; Reutens, D.C.; Sobey, C.G. Apoptotic mechanisms after cerebral ischemia. Stroke 2009, 40, e331-e339. [CrossRef]

66. Iadecola, C.; Alexander, M. Cerebral ischemia and inflammation. Curr. Opin. Neurol. 2001, 14, 89-94. [CrossRef]

67. Iadecola, C.; Anrather, J. The immunology of stroke: From mechanisms to translation. Nat. Med. 2011, 17, 796-808. [CrossRef]

68. Lipton, S.A.; Choi, Y.B.; Pan, Z.H.; Lei, S.Z.; Chen, H.S.; Sucher, N.J.; Loscalzo, J.; Singel, D.J.; Stamler, J.S. A redox-based mechanism for the neuroprotective and neurodestructive effects of nitric oxide and related nitroso-compounds. Nature 1993, 364, 626-632. [CrossRef] [PubMed]

69. Marozkina, N.V.; Gaston, B. S-Nitrosylation signaling regulates cellular protein interactions. Biochim. Biophys. Acta Gen. Subj. 2012, 1820, 722-729. [CrossRef] [PubMed]

70. Lipton, S.A. Neuronal protection and destruction by NO. Cell Death Differ. 1999, 6, 943-951. [CrossRef] [PubMed]

71. Sha, Y.; Marshall, H.E. S-nitrosylation in the regulation of gene transcription. Biochim. Biophys. Acta Gen. Subj. 2012, 1820 , 701-711. [CrossRef] [PubMed]

72. Chung, H.S.; Murray, C.I.; Venkatraman, V.; Crowgey, E.L.; Rainer, P.P.; Cole, R.N.; Bomgarden, R.D.; Rogers, J.C.; Balkan, W.; Hare, J.M.; et al. Dual Labeling Biotin Switch Assay to Reduce Bias Derived From Different Cysteine Subpopulations: A Method to Maximize S-Nitrosylation Detection. Circ. Res. 2015, 117, 846-857. [CrossRef]

73. Doulias, P.-T.; Greene, J.L.; Greco, T.M.; Tenopoulou, M.; Seeholzer, S.H.; Dunbrack, R.L.; Ischiropoulos, H. Structural profiling of endogenous S-nitrosocysteine residues reveals unique features that accommodate diverse mechanisms for protein S-nitrosylation. Proc. Natl. Acad. Sci. USA 2010, 107, 16958-16963. [CrossRef]

74. Yao, D.; Gu, Z.; Nakamura, T.; Shi, Z.-Q.; Ma, Y.; Gaston, B.; Palmer, L.A.; Rockenstein, E.M.; Zhang, Z.; Masliah, E.; et al. Nitrosative stress linked to sporadic Parkinson's disease: S-nitrosylation of parkin regulates its E3 ubiquitin ligase activity. Proc. Natl. Acad. Sci. USA 2004, 101, 10810-10814. [CrossRef]

75. Chen, T.; Cao, L.; Dong, W.; Luo, P.; Liu, W.; Qu, Y.; Fei, Z. Protective effects of mGluR5 positive modulators against traumatic neuronal injury through PKC-dependent activation of MEK/ERK pathway. Neurochem. Res. 2012, 37, 983-990. [CrossRef]

76. Qu, Z.W.; Miao, W.Y.; Hu, S.Q.; Li, C.; Zhuo, X.L.; Zong, Y.Y.; Wu, Y.P.; Zhang, G.Y. N-Methyl-D-Aspartate Receptor-Dependent Denitrosylation of Neuronal Nitric Oxide Synthase Increase the Enzyme Activity. PLoS ONE 2012, 7, e52788. [CrossRef]

77. Ravi, K.; Brennan, L.A.; Levic, S.; Ross, P.A.; Black, S.M. S-nitrosylation of endothelial nitric oxide synthase is associated with monomerization and decreased enzyme activity. Proc. Natl. Acad. Sci. USA 2004, 101, 2619-2624. [CrossRef] [PubMed]

78. Erwin, P.A.; Lin, A.J.; Golan, D.E.; Michel, T. Receptor-regulated dynamic S-nitrosylation of endothelial nitric-oxide synthase in vascular endothelial cells. J. Biol. Chem. 2005, 280, 19888-19894. [CrossRef]

79. Hara, M.R.; Agrawal, N.; Kim, S.F.; Cascio, M.B.; Fujimuro, M.; Ozeki, Y.; Takahashi, M.; Cheah, J.H.; Tankou, S.K.; Hester, L.D.; et al. S-nitrosylated GAPDH initiates apoptotic cell death by nuclear translocation following Siah1 binding. Nat. Cell Biol. 2005, 7, 665-674. [CrossRef] [PubMed]

80. Li, C.; Feng, J.J.; Wu, Y.P.; Zhang, G.Y. Cerebral ischemia-reperfusion induces GAPDH S-nitrosylation and nuclear translocation. Biochemistry (Moscow) 2012, 77, 671-678. [CrossRef] [PubMed]

81. Gu, Z.; Kaul, M.; Yan, B.; Kridel, S.J.; Cui, J.; Strongin, A.; Smith, J.W.; Liddington, R.C.; Lipton, S.A. S-nitrosylation of matrix metalloproteinases: Signaling pathway to neuronal cell death. Science 2002, 297, 1186-1190. [CrossRef] [PubMed]

82. Tristan, C.; Shahani, N.; Sedlak, T.W.; Sawa, A. The diverse functions of GAPDH: Views from different subcellular compartments. Cell. Signal. 2011, 23, 317-323. [CrossRef]

83. Tanaka, R.; Mochizuki, H.; Suzuki, A.; Katsube, N.; Ishitani, R.; Mizuno, Y.; Urabe, T. Induction of glyceraldehyde-3-phosphate dehydrogenase (GAPDH) expression in rat brain after focal ischemia/reperfusion. J. Cereb. Blood Flow Metab. 2002, 22, 280-288. [CrossRef] [PubMed] 
84. Helton, R.; Cui, J.; Scheel, J.R.; Ellison, J.A.; Ames, C.; Gibson, C.; Blouw, B.; Ouyang, L.; Dragatsis, I.; Zeitlin, S.; et al. Brainspecific knock-out of hypoxia-inducible factor-1alpha reduces rather than increases hypoxic-ischemic damage. J. Neurosci. 2005, 25, 4099-4107. [CrossRef] [PubMed]

85. Barteczek, P.; Li, L.; Ernst, A.-S.; Böhler, L.-I.; Marti, H.H.; Kunze, R. Neuronal HIF-1 $\alpha$ and HIF-2 $\alpha$ deficiency improves neuronal survival and sensorimotor function in the early acute phase after ischemic stroke. J. Cereb. Blood Flow Metab. 2017, 37, 291-306. [CrossRef] [PubMed]

86. Lando, D.; Peet, D.J.; Gorman, J.J.; Whelan, D.A.; Whitelaw, M.L.; Bruick, R.K. FIH-1 is an asparaginyl hydroxylase enzyme that regulates the transcriptional activity of hypoxia-inducible factor. Genes Dev. 2002, 16, 1466-1471. [CrossRef]

87. Chen, R.L.; Ogunshola, O.O.; Yeoh, K.K.; Jani, A.; Papadakis, M.; Nagel, S.; Schofield, C.J.I.; Buchan, A.M. HIF prolyl hydroxylase inhibition prior to transient focal cerebral ischaemia is neuroprotective in mice. J. Neurochem. 2014, 131, 177-189. [CrossRef]

88. Semenza, G.L. Hypoxia-inducible factor 1: Master regulator of O2 homeostasis. Curr. Opin. Genet. Dev. 1998, 8, 588-594. [CrossRef]

89. Semenza, G.L.; Wang, G.L. A nuclear factor induced by hypoxia via de novo protein synthesis binds to the human erythropoietin gene enhancer at a site required for transcriptional activation. Mol. Cell. Biol. 1992, 12, 5447-5454. [CrossRef]

90. Manalo, D.J.; Rowan, A.; Lavoie, T.; Natarajan, L.; Kelly, B.D.; Ye, S.Q.; Garcia, J.G.N.; Semenza, G.L. Transcriptional regulation of vascular endothelial cell responses to hypoxia by HIF-1. Blood 2005, 105, 659-669. [CrossRef]

91. Semenza, G.L.; Nejfelt, M.K.; Chi, S.M.; Antonarakis, S.E. Hypoxia-inducible nuclear factors bind to an enhancer element located $3^{\prime}$ to the human erythropoietin gene. Proc. Natl. Acad. Sci. USA 1991, 88, 5680-5684. [CrossRef]

92. Khan, M.; Dhammu, T.S.; Dhaindsa, T.S. An NO/GSNO-based Neuroregeneration Strategy for Stroke Therapy. J. Neurol. Neurosci. 2015, 6, 58. [CrossRef] [PubMed]

93. Khan, M.; Khan, H.; Singh, I.; Singh, A.K. Hypoxia inducible factor-1 alpha stabilization for regenerative therapy in traumatic brain injury. Neural Regen. Res. 2017, 12, 696-701. [CrossRef]

94. Khan, M.; Dhammu, T.S.; Baarine, M.; Kim, J.; Paintlia, M.K.; Singh, I.; Singh, A.K. GSNO promotes functional recovery in experimental TBI by stabilizing HIF-1 $\alpha$. Behav. Brain Res. 2016, 340, 63-70. [CrossRef]

95. Kaelin, W.G.; Ratcliffe, P.J. Oxygen sensing by metazoans: The central role of the HIF hydroxylase pathway. Mol. Cell 2008, 30, 393-402. [CrossRef] [PubMed]

96. Ogle, M.E.; Gu, X.; Espinera, A.R.; Wei, L. Inhibition of prolyl hydroxylases by dimethyloxaloylglycine after stroke reduces ischemic brain injury and requires hypoxia inducible factor-1 $\alpha$. Neurobiol. Dis. 2012, 45, 733-742. [CrossRef] [PubMed]

97. Moro, M.A.; Alba, J.D.; Leza, J.C.; Lorenzo, P.; Fernández, A.P.; Bentura, M.L.; Boscá, L.; Rodrigo, J.; Lizasoain, I. Neuronal expression of inducible nitric oxide synthase after oxygen and glucose deprivation in rat forebrain slices. Eur. J. Neurosci. 1998, 10, 445-456. [CrossRef]

98. Matrone, C.; Pignataro, G.; Molinaro, P.; Irace, C.; Scorziello, A.; Di Renzo, G.F.; Annunziato, L.; Renzo, G.F.D.; Annunziato, L. HIF-1alpha reveals a binding activity to the promoter of iNOS gene after permanent middle cerebral artery occlusion. $J$. Neurochem. 2004, 90, 368-378. [CrossRef] [PubMed]

99. Zhang, Z.; Yan, J.; Shi, H. Role of Hypoxia Inducible Factor 1 in Hyperglycemia-Exacerbated Blood-Brain Barrier Disruption in Ischemic Stroke. Neurobiol. Dis. 2016, 95, 82-92. [CrossRef]

100. Li, Q.F.; Xu, H.; Sun, Y.; Hu, R.; Jiang, H. Induction of inducible nitric oxide synthase by isoflurane post-conditioning via hypoxia inducible factor- $1 \alpha$ during tolerance against ischemic neuronal injury. Brain Res. 2012, 1451, 1-9. [CrossRef] [PubMed]

101. Baranova, O.; Miranda, L.F.; Pichiule, P.; Dragatsis, I.; Johnson, R.S.; Chavez, J.C. Neuron-specific inactivation of the hypoxia inducible factor $1 \alpha$ increases brain injury in a mouse model of transient focal cerebral ischemia. J. Neurosci. 2007, 27, 6320-6332. [CrossRef]

102. Kunze, R.; Zhou, W.; Veltkamp, R.; Wielockx, B.; Breier, G.; Marti, H.H. Neuron-specific prolyl-4-hydroxylase domain 2 knockout reduces brain injury after transient cerebral ischemia. Stroke 2012, 43, 2748-2756. [CrossRef]

103. Bok, S.; Kim, Y.E.; Woo, Y.; Kim, S.; Kang, S.J.; Lee, Y.; Park, S.K.; Weissman, I.L.; Ahn, G.O. Hypoxia-inducible factor-1a regulates microglial functions affecting neuronal survival in the acute phase of ischemic stroke in mice. Oncotarget 2017, 8, 111508-111521. [CrossRef]

104. Huang, T.; Huang, W.; Zhang, Z.; Yu, L.; Xie, C.; Zhu, D.; Peng, Z.; Chen, J. Hypoxia-inducible factor-1 $\alpha$ upregulation in microglia following hypoxia protects against ischemia-induced cerebral infarction. Neuroreport 2014, 25, 1122-1128. [CrossRef]

105. Hsiao, G.; Lee, J.-J.J.; Chen, Y.-C.C.; Lin, J.-H.H.; Shen, M.-Y.Y.; Lin, K.-H.H.; Chou, D.-S.S.; Sheu, J.-R.R. Neuroprotective effects of PMC, a potent $\alpha$-tocopherol derivative, in brain ischemia-reperfusion: Reduced neutrophil activation and anti-oxidant actions. Biochem. Pharmacol. 2007, 73, 682-693. [CrossRef] [PubMed]

106. Luciano, J.A.; Tan, T.; Zhang, Q.; Huang, E.; Scholz, P.; Weiss, H.R. Hypoxia inducible factor-1 improves the actions of nitric oxide and natriuretic peptides after simulated ischemia-reperfusion. Cell. Physiol. Biochem. 2008, 21, 421-428. [CrossRef] [PubMed]

107. Shi, H. Hypoxia Inducible Factor 1 as a Therapeutic Target in Ischemic Stroke. Curr. Med. Chem. 2009, 16, 4593. [CrossRef]

108. Aminova, L.R.; Chavez, J.C.; Lee, J.; Ryu, H.; Kung, A.; Lamanna, J.C.; Ratan, R.R. Prosurvival and prodeath effects of hypoxiainducible factor-1alpha stabilization in a murine hippocampal cell line. J. Biol. Chem. 2005, 280, 3996-4003. [CrossRef] [PubMed]

109. Wiesener, M.S.; Turley, H.; Allen, W.E.; Willam, C.; Eckardt, K.U.; Talks, K.L.; Wood, S.M.; Gatter, K.C.; Harris, A.L.; Pugh, C.W.; et al. Induction of endothelial PAS domain protein-1 by hypoxia: Characterization and comparison with hypoxia-inducible factor-1alpha. Blood 1998, 92, 2260-2268. [CrossRef] [PubMed] 
110. Wiesener, M.S.; Jürgensen, J.S.; Rosenberger, C.; Scholze, C.K.; Hörstrup, J.H.; Warnecke, C.; Mandriota, S.; Bechmann, I.; Frei, U.A.; Pugh, C.W.; et al. Widespread hypoxia-inducible expression of HIF-2alpha in distinct cell populations of different organs. FASEB J. 2003, 17, 271-273. [CrossRef]

111. Brusselmans, K.; Compernolle, V.; Tjwa, M.; Wiesener, M.S.; Maxwell, P.H.; Collen, D.; Carmeliet, P. Heterozygous deficiency of hypoxia-inducible factor-2alpha protects mice against pulmonary hypertension and right ventricular dysfunction during prolonged hypoxia. J. Clin. Investig. 2003, 111, 1519-1527. [CrossRef] [PubMed]

112. Hu, C.-J.; Wang, L.-Y.; Chodosh, L.A.; Keith, B.; Simon, M.C. Differential roles of hypoxia-inducible factor 1alpha (HIF-1alpha) and HIF-2alpha in hypoxic gene regulation. Mol. Cell. Biol. 2003, 23, 9361-9374. [CrossRef] [PubMed]

113. Halterman, M.W.; Miller, C.C.; Federoff, H.J. Hypoxia-Inducible Factor-1 $\alpha$ Mediates Hypoxia-Induced Delayed Neuronal Death That Involves p53. J. Neurosci. 1999, 19, 6818-6824. [CrossRef]

114. Goda, N.; Ryan, H.E.; Khadivi, B.; McNulty, W.; Rickert, R.C.; Johnson, R.S. Hypoxia-inducible factor 1alpha is essential for cell cycle arrest during hypoxia. Mol. Cell. Biol. 2003, 23, 359-369. [CrossRef]

115. Renton, A.; Llanos, S.; Lu, X. Hypoxia induces p53 through a pathway distinct from most DNA-damaging and stress-inducing agents. Carcinogenesis 2003, 24, 1177-1182. [CrossRef]

116. Zivin, J.A. Factors determining the therapeutic window for stroke. Neurology 1998, 50, 599-603. [CrossRef]

117. Jaffer, H.; Morris, V.B.; Stewart, D.; Labhasetwar, V. Advances in stroke therapy. Drug Deliv. Transl. Res. 2011. [CrossRef]

118. Wung, B.S.; Cheng, J.J.; Shyue, S.K.; Wang, D.L. NO modulates monocyte chemotactic prootein-1 expression in endothelial cells under cyclic strain. Arterioscler. Thromb. Vasc. Biol. 2001, 21, 1941-1947. [CrossRef] [PubMed]

119. Begum, N.; Sandu, O.A.; Duddy, N. Negative regulation of Rho signaling by insulin and its impact on actin cytoskeleton organization in vascular smooth muscle cells: Role of nitric oxide and cyclic guanosine monophosphate signaling pathways. Diabetes 2002, 51, 2256-2263. [CrossRef]

120. Hirabayashi, H.; Takizawa, S.; Fukuyama, N.; Nakazawa, H.; Shinohara, Y. Nitrotyrosine generation via inducible nitric oxide synthase in vascular wall in focal ischemia-reperfusion. Brain Res. 2000, 852, 319-325. [CrossRef]

121. Gow, A.; Duran, D.; Thom, S.R.; Ischiropoulos, H. Carbon Dioxide Enhancement of Peroxynitrite-Mediated Protein Tyrosine Nitration. Arch. Biochem. Biophys. 1996, 333, 42-48. [CrossRef] [PubMed]

122. Chandel, N.S.; McClintock, D.S.; Feliciano, C.E.; Wood, T.M.; Melendez, J.A.; Rodriguez, A.M.; Schumacker, P.T. Reactive oxygen species generated at mitochondrial complex III stabilize hypoxia-inducible factor-1alpha during hypoxia: A mechanism of $\mathrm{O} 2$ sensing. J. Biol. Chem. 2000, 275, 25130-25138. [CrossRef]

123. Sanjuán-Pla, A.; Cervera, A.M.; Apostolova, N.; Garcia-Bou, R.; Víctor, V.M.; Murphy, M.P.; McCreath, K.J. A targeted antioxidant reveals the importance of mitochondrial reactive oxygen species in the hypoxic signaling of HIF-1alpha. FEBS Lett. 2005, 579, 2669-26674. [CrossRef] [PubMed]

124. Kikuchi, K.; Tancharoen, S.; Takeshige, N.; Yoshitomi, M.; Morioka, M.; Murai, Y.; Tanaka, E. The efficacy of edaravone (radicut), a free radical scavenger, for cardiovascular disease. Int. J. Mol. Sci. 2013, 14, 13909-13930. [CrossRef]

125. Satoh, K.; Ikeda, Y.; Shioda, S.; Tobe, T.; Yoshikawa, T. Edarabone scavenges nitric oxide. Redox Rep. 2002, 7, 219-222. [CrossRef] [PubMed]

126. Banno, M.; Mizuno, T.; Kato, H.; Zhang, G.; Kawanokuchi, J.; Wang, J.; Kuno, R.; Jin, S.; Takeuchi, H.; Suzumura, A. The radical scavenger edaravone prevents oxidative neurotoxicity induced by peroxynitrite and activated microglia. Neuropharmacology 2005, 48, 283-290. [CrossRef]

127. Watanabe, T.; Yuki, S.; Egawa, M.; Nishi, H. Protective effects of MCI-186 on cerebral ischemia: Possible involvement of free radical scavenging and antioxidant actions. J. Pharmacol. Exp. Ther. 1994, 268, 1597-1604.

128. Feng, S.; Yang, Q.; Liu, M.; Li, W.; Yuan, W.; Zhang, S.; Wu, B.; Li, J. Edaravone for acute ischaemic stroke. Cochrane Database Syst. Rev. 2011, 12, CD007230. [CrossRef]

129. Otomo, E.; Tohgi, H.; Kogure, K.; Hirai, S.; Takakura, K.; Terashi, A.; Gotoh, F.; Maruyama, S.; Tazaki, Y.; Shinohara, Y.; et al. Effect of a novel free radical scavenger, edaravone (MCI-186), on acute brain infarction: Randomized, placebo-controlled, double-blind study at multicenters. Cerebrovasc. Dis. 2003, 15, 222-229.

130. The RANTTAS Investigators. A randomized trial of tirilazad mesylate in patients with acute stroke (RANTTAS). Stroke 1996, 27, 1453-1458. [CrossRef]

131. The Tirilazad International Steering Committee. Tirilazad for acute ischaemic stroke. Cochrane Database Syst. Rev. 2001, CD002087. [CrossRef]

132. Saito, I.; Asano, T.; Sano, K.; Takakura, K.; Abe, H.; Yoshimoto, T.; Kikuchi, H.; Ohta, T.; Ishibashi, S. Neuroprotective effect of an antioxidant, ebselen, in patients with delayed neurological deficits after aneurysmal subarachnoid hemorrhage. Neurosurgery 1998, 42, 269-277. [CrossRef]

133. Ogawa, A.; Yoshimoto, T.; Kikuchi, H.; Sano, K.; Saito, I.; Yamaguchi, T.; Yasuhara, H. Ebselen in acute middle cerebral artery occlusion: A placebo-controlled, double-blind clinical trial. Cerebrovasc. Dis. 1999, 9, 112-118. [CrossRef]

134. Yamaguchi, T.; Sano, K.; Takakura, K.; Saito, I.; Shinohara, Y.; Asano, T.; Yasuhara, H. Ebselen in acute ischemic stroke: A placebo-controlled, double-blind clinical trial. Stroke 1998, 29, 12-17. [CrossRef] [PubMed]

135. Morikawa, E.; Rosenblatt, S.; Moskowitz, M.A. l-Arginine dilates rat pial arterioles by nitric oxide-dependent mechanisms and increases blood flow during focal cerebral ischaemia. Br. J. Pharmacol. 1992, 107, 905-907. [CrossRef] [PubMed] 
136. Morikawa, E.; Huang, Z.; Moskowitz, M.A. L-Arginine decreases infarct size caused by middle cerebral arterial occlusion in SHR. Am. J. Physiol. Hear. Circ. Physiol. 1992, 263, H1632-H1635. [CrossRef] [PubMed]

137. Morikawa, E.; Moskowitz, M.A.; Huang, Z.; Yoshida, T.; Irikura, K.; Dalkara, T. L-arginine infusion promotes nitric oxidedependent vasodilation, increases regional cerebral blood flow, and reduces infarction volume in the rat. Stroke 1994, 25, 429-435. [CrossRef]

138. Zhao, H.; Asai, S.; Ishikawa, K. Neither L-NAME nor L-arginine changes extracellular glutamate elevation and anoxic depolarization during global ischemia and reperfusion in rat. Neuroreport 1999, 10, 313-318. [CrossRef]

139. Kurt, T.; Oğuzhanoğlu, A.; Ortaç, R.; Turman, B.; Adigüzel, E. Effects of L-arginine on the brain ischaemia-reperfusion damage in rats: An investigation by somatosensory evoked potentials and histopathology. Neurosci. Res. Commun. 2002, 31, 175-182. [CrossRef]

140. Zhao, X.; Ross, M.E.; Iadecola, C. L-arginine increases ischemic injury in wild-type mice but not in iNOS-deficient mice. Brain Res. 2003, 966, 308-311. [CrossRef]

141. Alderton, W.K.; Cooper, C.E.; Knowles, R.G. Nitric oxide synthases: Structure, function and inhibition. Biochem. J. 2001, 357, 593-615. [CrossRef] [PubMed]

142. Schmidt, H.H.; Warner, T.D.; Ishii, K.; Sheng, H.; Murad, F. Insulin secretion from pancreatic B cells caused by L-arginine-derived nitrogen oxides. Science 1992, 255, 721-723. [CrossRef]

143. Takahashi, K.; Yamatani, K.; Hara, M.; Sasaki, H. Gliclazide directly suppresses arginine-induced glucagon secretion. Diabetes Res. Clin. Pract. 1994, 24, 143-151. [CrossRef]

144. Alba-Roth, J.; Müller, O.A.; Schopohl, J.; Von Werder, K. Arginine stimulates growth hormone secretion by suppressing endogenous somatostatin secretion. J. Clin. Endocrinol. Metab. 1988, 67, 1186-1189. [CrossRef]

145. Strasser, A.; McCarron, R.M.; Ishii, H.; Stanimirovic, D.; SpatZ, M. L-arginine induces dopamine release from the striatum in vivo. Neuroreport 1994, 5, 2298-2300. [CrossRef] [PubMed]

146. Li, G.; Regunathan, S.; Barrow, C.J.; Eshraghi, J.; Cooper, R.; Reis, D.J. Agmatine: An endogenous clonidine-displacing substance in the brain. Science 1994, 263, 966-969. [CrossRef]

147. Lortie, M.J.; Novotny, W.F.; Peterson, O.W.; Vallon, V.; Malvey, K.; Mendonca, M.; Satriano, J.; Insel, P.; Thomson, S.C.; Blantz, R.C. Agmatine, a bioactive metabolite of arginine. Production, degradation, and functional effects in the kidney of the rat. J. Clin. Investig. 1996, 97, 413-420. [CrossRef] [PubMed]

148. Sastre, M.; Galea, E.; Feinstein, D.; Reis, D.J.; Regunathan, S. Metabolism of agmatine in macrophages: Modulation by lipopolysaccharide and inhibitory cytokines. Biochem. J. 1998, 330, 1405-1409. [CrossRef]

149. Galea, E.; Regunathan, S.; Eliopoulos, V.; Feinstein, D.L.; Reis, D.J. Inhibition of mammalian nitric oxide synthases by agmatine, an endogenous polyamine formed by decarboxylation of arginine. Biochem. J. 1996, 316, 247-249. [CrossRef]

150. Zhang, R.; Zhang, L.; Zhang, Z.; Wang, Y.; Lu, M.; LaPointe, M.; Chopp, M. A nitric oxide donor induces neurogenesis and reduces functional deficits after stroke in rats. Ann. Neurol. 2001, 50, 602-611. [CrossRef]

151. Zhang, F.; Ladecola, C. Nitroprusside improves blood flow and reduces brain damage after focal ischemia. Neuroreport 1993, 4 , 559-562. [CrossRef]

152. Salom, J.B.; Ortí, M.; Centeno, J.M.; Torregrosa, G.; Alborch, E. Reduction of infarct size by the NO donors sodium nitroprusside and spermine/NO after transient focal cerebral ischemia in rats. Brain Res. 2000, 865, 149-156. [CrossRef]

153. Zhang, F.; White, J.G.; Iadecola, C. Nitric oxide donors increase blood flow and reduce brain damage in focal ischemia: Evidence that nitric oxide is beneficial in the early stages of cerebral ischemia. J. Cereb. Blood Flow Metab. 1994, 14, 217-226. [CrossRef]

154. Zhang, F.; Iadecola, C. Reduction of focal cerebral ischemic damage by delayed treatment with nitric oxide donors. J. Cereb. Blood Flow Metab. 1994, 14, 574-580. [CrossRef]

155. Zhuang, P.; Ji, H.; Zhang, Y.H.; Min, Z.L.; Ni, Q.G.; You, R. ZJM-289, a novel nitric oxide donor, alleviates the cerebral ischaemicreperfusion injury in rats. Clin. Exp. Pharmacol. Physiol. 2010, 37, e121-e127. [CrossRef]

156. Martínez-Murillo, R.; Fernández, A.P.; Serrano, J.; Rodrigo, J.; Salas, E.; Mourelle, M.; Martínez, A. The nitric oxide donor LA 419 decreases brain damage in a focal ischemia model. Neurosci. Lett. 2007, 415, 149-153. [CrossRef] [PubMed]

157. Serrano, J.; Fernández, A.P.; Martínez-Murillo, R.; Alonso, D.; Rodrigo, J.; Salas, E.; Mourelle, M.; Martínez, A. The nitric oxide donor LA 419 decreases ischemic brain damage. Int. J. Mol. Med. 2007, 19, 229-236. [CrossRef] [PubMed]

158. Butterworth, R.J.; Cluckie, A.; Jackson, S.H.D.; Buxton-Thomas, M.; Bath, P.M.W. Pathophysiological assessment of nitric oxide (given as sodium nitroprusside) in acute ischaemic stroke. Cerebrovasc. Dis. 1998, 8, 158-165. [CrossRef] [PubMed]

159. Thomas, J.E.; Rosenwasser, R.H.; Armonda, R.A.; Harrop, J.; Mitchell, W.; Galaria, I. Safety of intrathecal sodium nitroprusside for the treatment and prevention of refractory cerebral vasospasm and ischemia in humans. Stroke 1999, 30, 1409-1416. [CrossRef]

160. Khan, M.; Jatana, M.; Elango, C.; Singh Paintlia, A.; Singh, A.K.; Singh, I. Cerebrovascular protection by various nitric oxide donors in rats after experimental stroke. Nitric Oxide 2006, 15, 114-124. [CrossRef]

161. Khan, M.; Sekhon, B.; Giri, S.; Jatana, M.; Gilg, A.G.; Ayasolla, K.; Elango, C.; Singh, A.K.; Singh, I. S-Nitrosoglutathione reduces inflammation and protects brain against focal cerebral ischemia in a rat model of experimental stroke. J. Cereb. Blood Flow Metab. 2005, 25, 177-192. [CrossRef]

162. Barakat, W.; Fahmy, A.; Askar, M.; El-Kannishy, S. Effectiveness of arginase inhibitors against experimentally induced stroke. Naunyn. Schmiedebergs. Arch. Pharmacol. 2018, 391, 603-612. [CrossRef] 
163. Jung, C.S.; Iuliano, B.A.; Harvey-White, J.; Espey, M.G.; Oldfield, E.H.; Pluta, R.M. Association between cerebrospinal fluid levels of asymmetric dimethyl-L-arginine, an endogenous inhibitor of endothelial nitric oxide synthase, and cerebral vasospasm in a primate model of subarachnoid hemorrhage. J. Neurosurg. 2004, 101, 836-842. [CrossRef] [PubMed]

164. Willmot, M.; Gibson, C.; Gray, L.; Murphya, S.; Batha, P.; Murphy, S.; Bath, P. Nitric oxide synthase inhibitors in experimental ischemic stroke and their effects on infarct size and cerebral blood flow: A systematic review. Free Radic. Biol. Med. 2005, 39, 412-425. [CrossRef] [PubMed]

165. Margaill, I.; Allix, M.; Boulu, R.G.; Plotkine, M. Dose- and time-dependence of L-NAME neuroprotection in transient focal cerebral ischaemia in rats. Br. J. Pharmacol. 1997, 120, 160-163. [CrossRef]

166. Fukuda, S.; Hashimoto, N.; Naritomi, H.; Nagata, I.; Nozaki, K.; Kondo, S.; Kurino, M.; Kikuchi, H. Prevention of rat cerebral aneurysm formation by inhibition of nitric oxide synthase. Circulation 2000, 101, 2532-2538. [CrossRef] [PubMed]

167. Zhang, F.; Casey, R.M.; Ross, M.E.; Iadecola, C. Aminoguanidine ameliorates and L-arginine worsens brain damage from intraluminal middle cerebral artery occlusion. Stroke 1996, 27, 317-323. [CrossRef] [PubMed]

168. Kidd, G.A.; Hong, H.; Majid, A.; Kaufman, D.I.; Chen, A.F. Inhibition of brain GTP cyclohydrolase I and tetrahydrobiopterin attenuates cerebral infarction via reducing inducible NO synthase and peroxynitrite in ischemic stroke. Stroke 2005, 36, 2705-2711. [CrossRef]

169. Yin, X.; Yan, J.; Hou, X.; Wu, S.; Zgang, G. Neuroprotection of S-nitrosoglutathione against ischemic injury by down-regulating Fas S-nitrosylation and downstream signaling. Neuroscience 2013, 248, 209-298. [CrossRef]

170. Yu, L.-M.; Zhang, T.-Y.; Yin, X.-H.; Yang, Q.; Lu, F.; Yan, J.-Z.; Li, C. Denitrosylation of nNOS induced by cerebral ischemiareperfusion contributes to nitrosylation of CaMKII and its inhibition of autophosphorylation in hippocampal CA1. Eur. Rev. Med. Pharmacol. Sci. 2019, 23, 7674-7683.

171. Khan, M.; Dhammu, T.S.; Qiao, F.; Kumar, P.; Singh, A.K.; Singh, I. S-Nitrosoglutathione Mimics the Beneficial Activity of Endothelial Nitric Oxide Synthase-Derived Nitric Oxide in a Mouse Model of Stroke. J. Stroke Cerebrovasc. Dis. 2019, $28,104470$. [CrossRef] [PubMed]

172. Wei, X.W.; Hao, L.Y.; Qia, S.H. Inhibition on the S-nitrosylation of MKK4 can protect hippocampal CA1 neurons in rat cerebral ischemia/reperfusion. Brain Res. Bull. 2016, 124, 123-128. [CrossRef]

173. Zhao, Q.; Zhang, C.; Wang, X.; Chen, L.; Ji, H.; Zhang, Y. (S)-ZJM-289, a nitric oxide-releasing derivative of 3-n-butylphthalide, protects against ischemic neuronal injury by attenuating mitochondrial dysfunction and associated cell death. Neurochem. Int. 2012, 60, 134-144. [CrossRef]

174. Coert, B.A.; Anderson, R.E.; Meyer, F.B. A comparative study of the effects of two nitric oxide synthase inhibitors and two nitric oxide donors on temporary focal cerebral ischemia in the Wistar rat. J. Neurosurg. 1999, 90, 332-338. [CrossRef]

175. Coert, B.A.; Anderson, R.E.; Meyer, F.B. Effects of the nitric oxide donor 3-morpholinosydnonimine (SIN-1) in focal cerebral ischemia dependent on intracellular brain pH. J. Neurosurg. 2002, 97, 914-921. [CrossRef]

176. Zhang, P.; Guo, Z.; Xu, Y.; Li, Y.; Song, J. N-Butylphthalide (NBP) ameliorated cerebral ischemia reperfusion-induced brain injury via HGF-regulated TLR4/NF-кB signaling pathway. Biomed. Pharmacother. 2016, 83, 658-666. [CrossRef] [PubMed]

177. Jiang, M.H.; Kaku, T.; Hada, J.; Hayashi, Y. 7-Nitroindazole reduces nitric oxide concentration in rat hippocampus after transient forebrain ischemia. Eur. J. Pharmacol. 1999, 380, 117-121. [CrossRef]

178. Pramila, B.; Kalaivani, P.; Anita, A.; Saravana, C. l-NAME combats excitotoxicity and recuperates neurological deficits in MCAO/R rats. Pharmacol. Biochem. Behav. 2015, 134, 246-253. [CrossRef]

179. Nanri, K.; Montécot, C.; Springhetti, V.; Seylaz, J.; Pinard, E. The Selective Inhibitor of Neuronal Nitric Oxide Synthase, 7Nitroindazole, Reduces the Delayed Neuronal Damage Due to Forebrain Ischemia in Rats. Stroke 1998, 29, 1248-1254. [CrossRef]

180. Ding-Zhou, L.; Marchand-Verrecchia, C.; Croci, N.; Plotkine, M.; Margaill, I. L-NAME reduces infarction, neurological deficit and blood-brain barrier disruption following cerebral ischemia in mice. Eur. J. Pharmacol. 2002, 457, 137-146. [CrossRef]

181. Sun, M.; Zhao, Y.; Gu, Y.; Xu, C. Neuroprotective actions of aminoguanidine involve reduced the activation of calpain and caspase-3 in a rat model of stroke. Neurochem. Int. 2010, 56, 634-641. [CrossRef]

182. Zhu, D.Y.; Liu, S.H.; Sun, H.S.; Lu, Y.M. Expression of inducible nitric oxide synthase after focal cerebral ischemia stimulates neurogenesis in the adult rodent dentate gyrus. J. Neurosci. 2003, 23, 233-239. [CrossRef]

183. Sugimoto, K.; Iadecola, C. Effects of aminoguanidine on cerebral ischemia in mice: Comparison between mice with and without inducible nitric oxide synthase gene. Neurosci. Lett. 2002, 331, 25-28. [CrossRef]

184. Pérez-Asensio, F.J.; Hurtado, O.; Burguete, M.C.; Moro, M.A.; Salom, J.B.; Lizasoain, I.; Torregrosa, G.; Leza, J.C.; Alborch, E.; Castillo, J.; et al. Inhibition of iNOS activity by $1400 \mathrm{~W}$ decreases glutamate release and ameliorates stroke outcome after experimental ischemia. Neurobiol. Dis. 2005, 18, 375-384. [CrossRef]

185. Zheng, L.; Ding, J.; Wang, J.; Zhou, C.; Zhang, W. Effects and Mechanism of Action of Inducible Nitric Oxide Synthase on Apoptosis in a Rat Model of Cerebral Ischemia-Reperfusion Injury. Anat. Rec. Adv. Integr. Anat. Evol. Biol. 2016, $299,246-255$. [CrossRef]

186. Nagel, S.; Papadakis, M.; Chen, R.; Hoyte, L.C.; Brooks, K.J.; Gallichan, D.; Sibson, N.R.; Pugh, C.; Buchan, A.M. Neuroprotection by dimethyloxalylglycine following permanent and transient focal cerebral ischemia in rats. J. Cereb. Blood Flow Metab. 2011, 31, 132-143. [CrossRef]

187. Prass, K.; Ruscher, K.; Karsch, M.; Isaev, N.; Megow, D.; Priller, J.; Scharff, A.; Dirnagl, U.; Meisel, A. Desferrioxamine induces delayed tolerance against cerebral ischemia in vivo and in vitro. J. Cereb. Blood Flow Metab. 2002, 22, 520-525. [CrossRef] 
188. Reischl, S.; Li, L.; Walkinshaw, G.; Flippin, L.A.; Marti, H.H.; Kunze, R. Inhibition of HIF prolyl-4-hydroxylases by FG-4497 reduces brain tissue injury and edema formation during ischemic stroke. PLoS ONE 2014, 9, e84767. [CrossRef]

189. Siddiq, A.; Ayoub, I.A.; Chavez, J.C.; Aminova, L.; Shah, S.; LaManna, J.C.; Patton, S.M.; Connor, J.R.; Cherny, R.A.; Volitakis, I.; et al. Hypoxia-inducible factor prolyl 4-hydroxylase inhibition: A target for neuroprotection in the central nervous system. J. Biol. Chem. 2005, 280, 41732-41743. [CrossRef] [PubMed]

190. Harten, S.K.; Ashcroft, M.; Maxwell, P.H. Prolyl hydroxylase domain inhibitors: A route to HIF activation and neuroprotection. Antioxid. Redox Signal. 2010, 12, 459-480. [CrossRef]

191. Zaman, K.; Ryu, H.; Hall, D.; O’Donovan, K.; Lin, K.I.; Miller, M.P.; Marquis, J.C.; Baraban, J.M.; Semenza, G.L.; Ratan, R.R. Protection from oxidative stress-induced apoptosis in cortical neuronal cultures by iron chelators is associated with enhanced DNA binding of hypoxia-inducible factor-1 and ATF-1/CREB and increased expression of glycolytic enzymes, p21(waf1/cip1), and ery. J. Neurosci. 1999, 19, 9821-9830. [CrossRef]

192. Yin, W.; Clare, K.; Zhang, Q.; Volkow, N.D.; Du, C. Chronic cocaine induces HIF-VEGF pathway activation along with angiogenesis in the brain. PLoS ONE 2017, 12, e0175499. [CrossRef]

193. Zhang, B.; Tanaka, J.; Yang, L.; Yang, L.; Sakanaka, M.; Hata, R.; Maeda, N.; Mitsuda, N. Protective effect of vitamin E against focal brain ischemia and neuronal death through induction of target genes of hypoxia-inducible factor-1. Neuroscience 2004, 126, 433-440. [CrossRef]

194. Chern, C.M.; Liou, K.T.; Wang, Y.H.; Liao, J.F.; Yen, J.C.; Shen, Y.C. Andrographolide inhibits PI3K/AKT-dependent NOX2 and iNOS expression protecting mice against hypoxia/ischemia-induced oxidative brain injury. Planta Med. 2011, 77, 1669-1679. [CrossRef]

195. Huang, L.E.; Arany, Z.; Livingston, D.M.; Bunn, H.F. Activation of hypoxia-inducible transcription factor depends primarily upon redox-sensitive stabilization of its alpha subunit. J. Biol. Chem. 1996, 271, 32253-32259. [CrossRef]

196. Jeong, J.W.; Bae, M.K.; Ahn, M.Y.; Kim, S.H.; Sohn, T.K.; Bae, M.H.; Yoo, M.A.; Song, E.J.; Lee, K.J.; Kim, K.W. Regulationand destabilization of HIF-1alpha by ARD1-mediated acetylation. Cell 2002, 111, 709-720. [CrossRef]

197. Piret, J.-P.; Mottet, D.; Raes, M.; Michiels, C. Is HIF-1alpha apro- or an anti-apoptotic protein? Biochem. Pharmacol. 2002, 64, 889-892. [CrossRef]

198. Chang, Y.; Hsieh, C.Y.; Peng, Z.A.; Yen, T.L.; Hsiao, G.; Chou, D.S.; Chen, C.M.; Sheu, J.R. Neuroprotective mechanisms of puerarin in middle cerebral artery occlusion-induced brain infarction in rats. J. Biomed. Sci. 2009, 16, 9. [CrossRef] [PubMed]

199. Chen, C.; Hu, Q.; Yan, J.; Lei, J.; Qin, L.; Shi, X.; Luan, L.; Yang, L.; Wang, K.; Han, J.; et al. Multiple effects of 2 ME2 and D609 on the cortical expression of HIF-1 $\alpha$ and apoptotic genes in a middle cerebral artery occlusion-induced focal ischemia rat model. J. Neurochem. 2007, 102, 1831-1841. [CrossRef] [PubMed]

200. Bergeron, M.; Gidday, J.M.; Aimee, Y.Y.; Semenza, G.L.; Ferriero, D.M.; Sharp, F.R. Role of hypoxia-inducible factor-1 in hypoxia-induced ischemic tolerance in neonatal rat brain. Ann. Neurol. 2000, 48, 285-296. [CrossRef]

201. Freret, T.; Valable, S.; Chazalviel, L.; Saulnier, R.; Mackenzie, E.T.; Petit, E.; Bernaudin, M.; Boulouard, M.; Schumann-Bard, P. Delayed administration of deferoxamine reduces brain damage and promotes functional recovery after transient focal cerebral ischemia in the rat. Eur. J. Neurosci. 2006, 23, 1757-1765. [CrossRef]

202. Zhao, Y.; Rempe, D.A. Prophylactic neuroprotection against stroke: Low-dose, prolonged treatment with deferoxamine or deferasirox establishes prolonged neuroprotection independent of HIF-1 function. J. Cereb. Blood Flow Metab. 2011, 31, 1412-1423. [CrossRef]

203. Sharp, F.R.; Bergeron, M.; Bernaudin, M. Hypoxia-inducible factor in brain. In Hypoxia. Advances in Experimental Medicine and Biology; Roach, R.C., Wagner, P.D., Hackett, P., Eds.; Springer: Boston, MA, USA, 2001; Volume 502, pp. $273-291$.

204. Jones, N.M.; Bergeron, M. Hypoxic preconditioning induces changes in HIF-1 target genes in neonatal rat brain. J. Cereb. Blood Flow Metab. 2001, 21, 1105-1114. [CrossRef]

205. Kovalenko, T.N.; Ushakova, G.A.; Osadchenko, I.; Skibo, G.G.; Pierzynowski, S.G. The neuroprotective effect of 2-oxoglutarate in the experimental ischemia of hippocampus. J. Physiol. Pharmacol. 2011, 62, 239-246. [PubMed]

206. Zhou, J.; Li, J.; Rosenbaum, D.M.; Zhuang, J.; Poon, C.; Qin, P.; Rivera, K.; Lepore, J.; Willette, R.N.; Hu, E.; et al. The prolyl 4-hydroxylase inhibitor GSK360A decreases post-stroke brain injury and sensory, motor, and cognitive behavioral deficits. PLoS ONE 2017, 12, e0184049. [CrossRef] [PubMed]

207. Singh, A.; Wilson, J.W.; Schofield, C.J.; Chen, R. Hypoxia-inducible factor (HIF) prolyl hydroxylase inhibitors induce autophagy and have a protective effect in an in-vitro ischaemia model. Sci. Rep. 2020, 10, 1597. [CrossRef]

208. Sakanaka, M.; Wen, T.C.; Matsuda, S.; Masuda, S.; Morishita, E.; Nagao, M.; Sasaki, R. In vivo evidence that erythropoietin protects neurons from ischemic damage. Proc. Natl. Acad. Sci. USA 1998, 95, 4635-4640. [CrossRef] [PubMed]

209. Bernaudin, M.; Marti, H.H.; Roussel, S.; Divoux, D.; Nouvelot, A.; MacKenzie, E.T.; Petit, E. A potential role for erythropoietin in focal permanent cerebral ischemia in mice. J. Cereb. Blood Flow Metab. 1999, 19, 643-651. [CrossRef] [PubMed]

210. Sirén, A.L.; Fratelli, M.; Brines, M.; Goemans, C.; Casagrande, S.; Lewczuk, P.; Keenan, S.; Gleiter, C.; Pasquali, C.; Capobianco, A.; et al. Erythropoietin prevents neuronal apoptosis after cerebral ischemia and metabolic stress. Proc. Natl. Acad. Sci. USA 2001, 98, 4044-4049. [CrossRef] [PubMed]

211. Brines, M.L.; Ghezzi, P.; Keenan, S.; Agnello, D.; De Lanerolle, N.C.; Cerami, C.; Itri, L.M.; Cerami, A. Erythropoietin crosses the blood-brain barrier to protect against experimental brain injury. Proc. Natl. Acad. Sci. USA 2000, 97, 10526-10531. [CrossRef] 
212. Sadamoto, Y.; Igase, K.; Sakanaka, M.; Sato, K.; Otsuka, H.; Sakaki, S.; Masuda, S.; Sasaki, R. Erythropoietin prevents place navigation disability and cortical infarction in rats with permanent occlusion of the middle cerebral artery. Biochem. Biophys. Res. Commun. 1998, 253, 26-32. [CrossRef]

213. Gan, Y.; Xing, J.; Jing, Z.; Anne Stetler, R.; Zhang, F.; Luo, Y.; Ji, X.; Gao, Y.; Cao, G. Mutant erythropoietin without erythropoietic activity is neuroprotective against ischemic brain injury. Stroke 2012, 43, 3071-3077. [CrossRef]

214. Zhu, L.; Bai, X.; Wang, S.; Hu, Y.; Wang, T.; Qian, L.; Jiang, L. Recombinant human erythropoietin augments angiogenic responses in a neonatal rat model of cerebral unilateral hypoxia-ischemia. Neonatology 2014, 106, 143-148. [CrossRef]

215. Lee, S.T.; Chu, K.; Sinn, D.I.; Jung, K.H.; Kim, E.H.; Kim, S.J.; Kim, J.M.; Ko, S.Y.; Kim, M.; Roh, J.K. Erythropoietin reduces perihematomal inflammation and cell death with eNOS and STAT3 activations in experimental intracerebral hemorrhage. $J$. Neurochem. 2006, 96, 1728-1739. [CrossRef]

216. Sun, Y.; Jin, K.; Xie, L.; Childs, J.; Mao, X.O.; Logvinova, A.; Greenberg, D.A. VEGF-induced neuroprotection, neurogenesis, and angiogenesis after focal cerebral ischemia. J. Clin. Investig. 2003, 111, 1843-1851. [CrossRef]

217. Zhang, Z.G.; Zhang, L.; Jiang, Q.; Zhang, R.; Davies, K.; Powers, C.; Van Bruggen, N.; Chopp, M. VEGF enhances angiogenesis and promotes blood-brain barrier leakage in the ischemic brain. J. Clin. Investig. 2000, 106, 829-838. [CrossRef]

218. Amin, N.; Chen, S.; Ren, Q.; Tan, X.; Botchway, B.O.A.; Hu, Z.; Chen, F.; Ye, S.; Du, X.; Chen, Z.; et al. Hypoxia Inducible Factor-1 $\alpha$ Attenuates Ischemic Brain Damage by Modulating Inflammatory Response and Glial Activity. Cells 2021, 10, 1359. [CrossRef] [PubMed]

219. Yan, J.; Zhou, B.; Taheri, S.; Shi, H. Differential Effects of HIF-1 Inhibition by YC-1 on the Overall Outcome and Blood-Brain Barrier Damage in a Rat Model of Ischemic Stroke. PLoS ONE 2011, 6, e27798. [CrossRef] [PubMed]

220. El Khashab, I.H.; Abdelsalam, R.M.; Elbrairy, A.I.; Attia, A.S. Chrysin attenuates global cerebral ischemic reperfusion injury via suppression of oxidative stress, inflammation and apoptosis. Biomed. Pharmacother. 2019, 112, 108619. [CrossRef]

221. Yao, Y.; Chen, L.; Xiao, J.; Wang, C.; Jiang, W.; Zhang, R.; Hao, J. Chrysin Protects against Focal Cerebral Ischemia/Reperfusion Injury in Mice through Attenuation of Oxidative Stress and Inflammation. Int. J. Mol. Sci. 2014, 15, 20913-201926. [CrossRef]

222. Chen, W.; Jadhav, V.; Tang, J.; Zhang, J.H. HIF-1 $\alpha$ inhibition ameliorates neonatal brain injury in a rat pup hypoxic-ischemic model. Neurobiol. Dis. 2008, 31, 433-441. [CrossRef] [PubMed]

223. Guo, Y.; Zhou, J.; Li, X.; Xiao, Y.; Zhang, J.; Yang, Y.; Feng, L.; Kang, Y.J. The Association of Suppressed Hypoxia-Inducible Factor-1 Transactivation of Angiogenesis With Defective Recovery From Cerebral Ischemic Injury in Aged Rats. Front. Aging Neurosci. 2021, 13, 648115. [CrossRef] [PubMed]

224. Ehrenreich, H.; Hasselblatt, M.; Dembowski, C.; Cepek, L.; Lewczuk, P.; Stiefel, M.; Rustenbeck, H.H.; Breiter, N.; Jacob, S.; Knerlich, F.; et al. Erythropoietin therapy for acute stroke is both safe and beneficial. Mol. Med. 2002, 8, 495-505. [CrossRef]

225. Tsai, T.H.; Lu, C.H.; Wallace, C.G.; Chang, W.N.; Chen, S.F.; Huang, C.R.; Tsai, N.W.; Lan, M.Y.; Sung, P.H.; Liu, C.F.; et al. Erythropoietin improves long-term neurological outcome in acute ischemic stroke patients: A randomized, prospective, placebocontrolled clinical trial. Crit. Care 2015, 19, 49. [CrossRef] [PubMed]

226. Srivastava, K.; Bath, P.M.W.; Bayraktutan, U. Current therapeutic strategies to mitigate the eNOS dysfunction in ischaemic stroke. Cell. Mol. Neurobiol. 2012, 32, 319-336. [CrossRef]

227. Zhao, X.; Strong, R.; Piriyawat, P.; Palusinski, R.; Grotta, J.C.; Aronowski, J. Caffeinol at the receptor level: Anti-ischemic effect of n-methyl-d-aspartate receptor blockade is potentiated by caffeine. Stroke 2010, 41, 363-367. [CrossRef]

228. Dong, Z.S.W.; Cao, Z.P.; Shang, Y.J.; Liu, Q.Y.; Wu, B.Y.; Liu, W.X.; Li, C.H. Neuroprotection of cordycepin in NMDA-induced excitotoxicity by modulating adenosine A1 receptors. Eur. J. Pharmacol. 2019, 853, 325-335. [CrossRef]

229. Imai, K.; Mori, T.; Izumoto, H.; Takabatake, N.; Kunieda, T.; Watanabe, M. Hyperbaric oxygen combined with intravenous edaravone for treatment of acute embolic stroke: A pilot clinical trial. Neurol. Med. Chir. 2006, 46, 373-378. [CrossRef]

230. Kimura, K.; Aoki, J.; Sakamoto, Y.; Kobayashi, K.; Sakai, K.; Inoue, T.; Iguchi, Y.; Shibazaki, K. Administration of edaravone, a free radical scavenger, during t-PA infusion can enhance early recanalization in acute stroke patients-A preliminary study. J. Neurol. Sci. 2012, 313, 132-136. [CrossRef]

231. Aoki, J.; Kimura, K.; Morita, N.; Harada, M.; Metoki, N.; Tateishi, Y.; Todo, K.; Yamagami, H.; Hayashi, K.; Terasawa, Y.; et al YAMATO Study (Tissue-Type Plasminogen Activator and Edaravone Combination Therapy). Stroke 2017, 48, 712-719. [CrossRef]

232. Grotta, J.; Combination Therapy Stroke Trial Investigators. Combination therapy stroke trial: Recombinant tissue-type plasminogen activator with/without lubeluzole. Cerebrovasc. Dis. 2001, 12, 258-263. [CrossRef]

233. Montaner, J.; Bustamante, A.; García-Matas, S.; Martínez-Zabaleta, M.; Jiménez, C.; De La Torre, J.; Rubio, F.R.; Segura, T.; Masjuán, J.; Cánovas, D.; et al. Combination of thrombolysis and statins in acute stroke is safe: Results of the STARS randomized trial (Stroke Treatment With Acute Reperfusion and Simvastatin). Stroke 2016, 47, 2870-2873. [CrossRef] [PubMed]

234. Zhu, H.; Chandra, A.; Geng, X.; Cheng, Z.; Tong, Y.; Du, H.; Ding, Y. Low dose concomitant treatment with chlorpromazine and promethazine is safe in acute ischemic stroke. J. Neurosurg. Sci. 2019, 63, 265-269. [CrossRef] [PubMed]

235. Vellimana, A.K.; Milner, E.; Azad, T.D.; Harries, M.D.; Zhou, M.-L.L.; Gidday, J.M.; Han, B.H.; Zipfel, G.J. Endothelial nitric oxide synthase mediates endogenous protection against subarachnoid hemorrhage-induced cerebral vasospasm. Stroke 2011, 42, 776-782. [CrossRef]

236. Chen, S.; Li, N.; Deb-Chatterji, M.; Dong, Q.; Kielstein, J.T.; Weissenborn, K.; Worthmann, H. Asymmetric Dimethyarginine as marker and mediator in Ischemic stroke. Int. J. Mol. Sci. 2012, 13, 15983-16004. [CrossRef] [PubMed] 